\title{
Crop residue harvest for bioenergy production and its implications on soil functioning and plant growth: A review
}

\begin{abstract}
Maurício Roberto Cherubin ${ }^{1}$, Dener Márcio da Silva Oliveira ${ }^{3}$, Brigitte Josefine Feigl' ${ }^{1}$, Laisa Gouveia Pimentel ${ }^{3}$, Izaias Pinheiro Lisboa ${ }^{2}$, Maria Regina Gmach², Letícia Leal Varanda², Maristela Calvente Morais ${ }^{1}$, Lucas Santos Satiro², Gustavo Vicentini Popin², Sílvia Rodrigues de Paiva ${ }^{1}$, Arthur Klebson Belarmino dos Santos², Ana Luisa Soares de Vasconcelos ${ }^{1}$, Paul Lineker Amaral de Melo², Carlos Eduardo Pellegrino Cerri2* ${ }^{2 *}$ Carlos Clemente Cerri ${ }^{1+}$
\end{abstract}

'University of São Paulo/CENA, Av. Centenário, 303 13416-000 - Piracicaba, SP - Brazil.

2University of São Paulo/ESALQ - Dept. of Soil Science, Av. Pádua Dias, 11 - 13418-900 - Piracicaba, SP - Brazil.

${ }^{3}$ Federal Institute Goiano - Campus Posse, R. Correntina, 824 - 73900000 - Posse, GO - Brazil.

†In memoriam

*Corresponding author <cepcerri@usp.br>

Edited by: Paulo Cesar Sentelhas

Received November 16, 2016

Accepted February 27, 2017
ABSTRACT: The use of crop residues as a bioenergy feedstock is considered a potential strategy to mitigate greenhouse gas (GHG) emissions. However, indiscriminate harvesting of crop residues can induce deleterious effects on soil functioning, plant growth and other ecosystem services. Here, we have summarized the information available in the literature to identify and discuss the main trade-offs and synergisms involved in crop residue management for bioenergy production. The data consistently showed that crop residue harvest and the consequent lower input of organic matter into the soil led to $\mathrm{C}$ storage depletions over time, reducing cycling, supply and availability of soil nutrients, directly affecting the soil biota. Although the biota regulates key functions in the soil, crop residue can also cause proliferation of some important agricultural pests. In addition, crop residues act as physical barriers that protect the soil against raindrop impact and temperature variations. Therefore, intensive crop residue harvest can cause soil structure degradation, leading to soil compaction and increased risks of erosion. With regard to GHG emissions, there is no consensus about the potential impact of management of crop residue harvest. In general, residue harvest decreases $\mathrm{CO}_{2}$ and $\mathrm{N}_{2} \mathrm{O}$ emissions from the decomposition process, but it has no significant effect on $\mathrm{CH}_{4}$ emissions. Plant growth responses to soil and microclimate changes due to crop residue harvest are site and crop specific. Adoption of the best management practices can mitigate the adverse impacts of crop residue harvest. Longterm experiments within strategic production regions are essential to understand and monitor the impact of integrated agricultural systems and propose customized solutions for sustainable crop residue management in each region or landscape. Furthermore, private and public investments/cooperations are necessary for a better understanding of the potential environmental, economic and social implications of crop residue use for bioenergy production.

Keywords: bioenergy feedstock, soil quality, sugarcane, greenhouse gas emissions

\section{Introduction}

The gradual change in the energy mix, replacing fossil fuels for renewable energy sources is one of the principal ways to mitigate greenhouse gases (GHG) emissions and effects on global warming (IPCC, 2007). Thus, it is expected a significant increase of production of bioenergy in the near future to attend the growing global demand (IRENA, 2016). In this scenario, the stakeholders of this sector have increased their interest and investments to use crop residues as raw material for bioenergy production, mainly cellulosic ethanol (second-generation ethanol - E2G) and bioelectricity (Franco et al., 2013; Karlen and Johnson, 2014).

Currently, most crop residue is left in the field after harvesting and is underused for energy production. However, crop residues have an essential role to sustain and improve the chemical, physical and biological properties and soil processes, contributing to the suitable functioning of soil, plant growth and other environmental services (Blanco-Canqui and Lal, 2009; Lal, 2009; Franzluebbers, 2015; Carvalho et al., 2016; Stavi et al., 2016). Therefore, since that the use of crop resi- dues for energy production is a promising strategy on a global scale, the trade-offs and environmental synergism associated with crop residue management cannot be overlooked. Given the complexity of this subject, most research has been carried out to understand mechanisms and isolated processes, but few studies summarize and integrate this knowledge (e.g., Blanco-Canqui and Lal, 2009; Carvalho et al., 2016), which may support researchers and decision-makers within the bioenergy sector.

Thus, this review aimed to synthesize, gather and discuss information available in the literature on potential impacts of crop residue harvest on soil functioning, GHG emissions as well as its effects on plant growth and yield in areas for bioenergy purposes.

\section{Origin, quality and quantity of crop residues for bioenergy production}

Crop residues can be defined as the part of the plant that is left in the field after harvest, varying greatly in properties and decomposition rates (Lal, 2005). Globally, it is estimated that between 2003 and 2013, the production of agricultural residues increased by $33 \%$, 
reaching 5 billion Mg in 2013 (Table 1). The Asian continent is the largest producer of crop residues, $47 \%$ of the total, followed by America (29 \%) Europe (16 \%) Africa $(6 \%)$ and Oceania (2\%) Between 2003 and 2013, the production of crop residues in Brazil increased by approximately $41 \%$, reaching 432 million $\mathrm{Mg}$. This account for approximately $30 \%$ of the total production of the American continent and $9 \%$ of the global production.
With respect to energy supply, the crop residues of maize (Zea mays L.) and sugarcane (Saccharum spp. L.) emerge as the most important raw materials for the production of cellulosic ethanol and/or bioelectricity (Table 1). Other crops of global importance such as rice (Oryza sativa L.) and wheat (Triticum aestivum L.), are highlighted by the sheer volume of residues produced $144 \%$ of the total). However, both rice and wheat play a minor role in the production of biofuels. On the other hand,

Table 1 - Estimate crop residue production* (106 Mg) in 2003 and 2013 for Brazil, continents and the world.

\begin{tabular}{|c|c|c|c|c|c|c|c|c|c|c|c|c|c|c|}
\hline \multirow{2}{*}{ Crop } & \multicolumn{2}{|c|}{ Brazil } & \multicolumn{2}{|c|}{ America } & \multicolumn{2}{|c|}{ Asia } & \multicolumn{2}{|c|}{ Africa } & \multicolumn{2}{|c|}{ Europe } & \multicolumn{2}{|c|}{ Oceania } & \multicolumn{2}{|c|}{ World } \\
\hline & 2003 & 2013 & 2003 & 2013 & 2003 & 2013 & 2003 & 2013 & 2003 & 2013 & 2003 & 2013 & 2003 & 2013 \\
\hline \multicolumn{15}{|l|}{ Cereals } \\
\hline Barley & 0.5 & 0.4 & 32.0 & 31.6 & 32.1 & 33.7 & 8.7 & 11.0 & 124.8 & 128.7 & 16.1 & 11.8 & 213.8 & 217.1 \\
\hline Corn & 48.3 & 80.5 & 361.8 & 522.6 & 167.6 & 304.3 & 45.5 & 71.6 & 69.6 & 117.4 & 0.5 & 0.7 & 645.1 & 1016.7 \\
\hline Millet & - & - & 0.4 & 0.6 & 26.3 & 20.5 & 23.3 & 22.6 & 2.0 & 0.9 & 0.05 & 0.06 & 52.2 & 44.8 \\
\hline Oats & 0.4 & 0.4 & 6.8 & 6.6 & 1.1 & 1.1 & 0.1 & 0.2 & 16.3 & 14.5 & 2.0 & 1.1 & 26.5 & 23.8 \\
\hline Rice & 15.5 & 17.6 & 47.9 & 54.7 & 799.2 & 1012.2 & 27.7 & 43.9 & 4.8 & 5.8 & 0.6 & 1.7 & 880.5 & 1118.5 \\
\hline Rye & 0.005 & 0.006 & 0.8 & 0.6 & 1.5 & 1.7 & 0.04 & 0.1 & 19.3 & 22.4 & 0.03 & 0.05 & 21.9 & 25.0 \\
\hline Sorghum & 2.7 & 3.1 & 34.5 & 35.2 & 16.4 & 13.1 & 34.6 & 38.5 & 0.7 & 1.7 & 2.2 & 3.3 & 88.5 & 92.0 \\
\hline Wheat & 9.2 & 8.5 & 170.4 & 176.2 & 367.3 & 478.2 & 32.1 & 42.1 & 230.5 & 338.2 & 39.6 & 34.9 & 840.1 & 1069.7 \\
\hline Total & 76.6 & 110.5 & 654.6 & 828.1 & 1411.5 & 1864.8 & 172.0 & 230.0 & 468.0 & 629.6 & 61.0 & 53.6 & 2768.6 & 3607.6 \\
\hline \multicolumn{15}{|l|}{ Legumes } \\
\hline Beans & 3.3 & 2.9 & 7.3 & 7.0 & 10.0 & 10.6 & 3.0 & 4.8 & 0.4 & 0.5 & 0.05 & 0.5 & 20.9 & 23.1 \\
\hline Broad beans & 0.01 & 0.05 & 0.1 & 0.2 & 2.2 & 1.4 & 1.1 & 0.7 & 0.7 & 0.6 & 0.2 & 0.2 & 4.5 & 3.3 \\
\hline Chick peas & - & - & 0.2 & 0.5 & 6.2 & 11.0 & 0.3 & 0.5 & 0.08 & 0.09 & 0.1 & 0.8 & 7.1 & 13.1 \\
\hline Groundnut & 0.1 & 0.3 & 2.6 & 3.6 & 24.7 & 29.9 & 8.8 & 11.5 & 0.008 & 0.008 & 0.04 & 0.02 & 36.3 & 45.2 \\
\hline Lentils & - & - & 0.6 & 2.1 & 2.1 & 2.2 & 0.07 & 0.1 & 0.04 & 0.07 & 0.1 & 0.3 & 2.9 & 4.9 \\
\hline Peas & 0.06 & 0.04 & 2.3 & 4.7 & 2.1 & 2.2 & 0.3 & 0.7 & 4.5 & 3.0 & 0.5 & 0.2 & 9.8 & 10.9 \\
\hline Pulses & - & - & 0.02 & 0.03 & 1.4 & 2.1 & 1.1 & 1.2 & 0.8 & 1.2 & 0.006 & 0.5 & 3.5 & 5.2 \\
\hline Soybeans & 51.9 & 81.6 & 162.1 & 240.8 & 25.5 & 27.2 & 1.0 & 2.2 & 1.8 & 5.9 & 0.009 & 0.9 & 190.6 & 276.4 \\
\hline Total & 55.3 & 84.8 & 175.2 & 258.9 & 74.2 & 86.6 & 15.6 & 21.7 & 8.3 & 11.3 & 1.0 & 3.4 & 275.6 & 382.1 \\
\hline \multicolumn{15}{|l|}{ Oil crops } \\
\hline Linseed & 0.006 & 0.01 & 1.0 & 0.8 & 0.6 & 0.7 & 0.1 & 0.1 & 0.2 & 0.4 & 0.008 & 0.009 & 2.0 & 2.2 \\
\hline Rapessed & 0.08 & 0.08 & 11.3 & 28.8 & 23.9 & 35.0 & 0.1 & 0.2 & 17.1 & 38.3 & 2.5 & 6.2 & 55.1 & 108.7 \\
\hline Safflower & - & - & 0.3 & 0.2 & 0.3 & 0.3 & 0.01 & 0.01 & 0.001 & 0.0009 & 0.02 & 0.004 & 0.7 & 0.6 \\
\hline Seed cotton & 3.3 & 5.1 & 19.7 & 18.7 & 53.4 & 78.8 & 7.0 & 6.4 & 2.0 & 1.5 & 1.3 & 4.0 & 83.7 & 109.5 \\
\hline Sesame & 0.03 & 0.01 & 0.2 & 0.2 & 4.3 & 4.9 & 1.8 & 4.2 & 0.002 & 0.002 & - & - & 6.4 & 9.5 \\
\hline Sunflower & 0.07 & 0.1 & 5.5 & 4.6 & 4.4 & 6.0 & 1.2 & 2.1 & 16.3 & 31.8 & 0.02 & 0.04 & 27.5 & 44.7 \\
\hline Total & 3.4 & 5.3 & 38.0 & 53.3 & 86.9 & 125.7 & 10.2 & 13.0 & 35.6 & 72.0 & 3.8 & 10.2 & 175.4 & 275.2 \\
\hline \multicolumn{15}{|l|}{ Sugar crop } \\
\hline Sugarbeet & - & - & 8.4 & 8.0 & 7.9 & 9.4 & 1.5 & 3.0 & 40.2 & 41.9 & - & - & 58.1 & 62.5 \\
\hline Sugarcane & 118.8 & 221.7 & 193.8 & 301.7 & 180.9 & 223.4 & 26.8 & 29.1 & 0.02 & 0.001 & 12.0 & 8.7 & 413.7 & 563.1 \\
\hline Total & 118.8 & 221.7 & 202.2 & 309.7 & 188.8 & 232.8 & 28.3 & 32.1 & 40.2 & 41.9 & 12.0 & 8.7 & 471.8 & 625.6 \\
\hline \multicolumn{15}{|l|}{ Tubers } \\
\hline Potato & 0.7 & 0.8 & 10.4 & 10.6 & 31.3 & 45.1 & 3.8 & 7.5 & 32.5 & 28.2 & 0.4 & 0.4 & 78.6 & 92.0 \\
\hline Sweet potato & 0.1 & 0.1 & 0.6 & 0.9 & 28.8 & 21.6 & 3.0 & 4.8 & 0.01 & 0.01 & 0.1 & 0.1 & 32.7 & 27.6 \\
\hline Total & 0.8 & 0.9 & 11.0 & 11.5 & 60.1 & 66.7 & 6.8 & 12.3 & 32.5 & 28.2 & 0.5 & 0.5 & 111.3 & 119.6 \\
\hline Grand total & 254.9 & 432.2 & 1081.0 & 1461.5 & 1821.5 & 2376.6 & 232.9 & 309.1 & 584.6 & 783.0 & 78.3 & 76.4 & 3330.9 & 5010.1 \\
\hline
\end{tabular}


soybean [Glycine max (L.) Merr.] and cotton (Gossipium hirsutum L.) residues, although available at large quantities (approximately 663 million $\mathrm{Mg}$ ), are considered noncollectable because of the small quantity produced per area and fast decomposition rates (Lal, 2005).

In Brazil, since the 2000s, the gradual elimination of sugarcane straw burning has promoted a notable increase in the quantity of residue left on the soil after harvesting (Manechini et al., 2005). This has made available a large quantity of straw that could be used for energy production. The amount of straw produced depends on factors such as sugarcane variety and edaphoclimatic conditions (Leal et al., 2013). On average, the straw represents 9 to $19 \%$ of the sugarcane dry weight (Landell et al., 2013), varying from 7.4 to $24.3 \mathrm{Mg} \mathrm{ha}^{-1}$ (average 14 $\mathrm{Mg} \mathrm{ha}^{-1}$ ) in Brazil (Paes and Oliveira, 2005).

Sugarcane straw has great potential for heat production, electricity and cellulosic ethanol (Santos et al., 2012). It is comprised mainly of cellulose (40-44 \%), hemicellulose (30-32 \%) and lignin (22-25\%) (Gomez et al., 2010), representing one third of the energy potential of the crop (Santos et al., 2012). Pereira et al. (2015) verified that the fermentability of hydrolysates from different sugarcane residues were in order: straw > tops > bagasse, indicating the large potential of straw and tops for the production of cellulosic ethanol (Pereira et al., 2015).

Short-term governmental projections (2016-2025) indicate that Brazil may produce 10 billion liters of cellulosic ethanol, half of current production of existing plants, another 1.5 billion liters arising from the increase in sugarcane milling and finally, 3.5 billion liters from new plants to be commissioned from 2020 onward (UNCTAD, 2016). In terms of bioelectricity, the burning of sugarcane residues supplied $4 \%$ of all the energy consumed in Brazil in 2015 (EPE, 2015), with potential to reach $18 \%$ in 2020/21 (EPE, 2013).

The use of crop residues from maize also has high potential for bioenergy production (Mitchell et al., 2016). Although this crop is grown in various countries worldwide, maize residue management is highlighted in the United States, the world's largest producer of ethanol from maize grains (ERS, 2016). After grain harvest, about $10 \mathrm{Mg} \mathrm{ha}^{-1}$ of dry material is left in the field (Lal, 2005), a substantial source of biomass for cellulosic ethanol production. Wilhelm et al. (2004) cited that maize residue could provide about 1.7 times more $\mathrm{C}$ than barley (Hordeum vulgare L.), oat (Avena sativa L.), sorghum [Sorghum bicolor (L.) Moench], wheat, soybean and sunflower (Helianthus annuus L.) residues based on production level. The carbohydrate content of the maize biomass fractions (leaves and stem from the superior third, cobs, leaves and stem from the inferior third of the plant) is quite variable. However, these variations had little or no effect on the potential for biofuel production, suggesting that the residual mass volume is the most influential factor (Mourtzinis et al., 2016).
The United States has a limited potential to increase the area planted with maize. Thus, the adoption of the best management practices and the use of plant breeding are essential to meet the national target of 61 billion $\mathrm{L} \mathrm{yr}^{-1}$ of biofuel derived from crop residues by 2022 (Bonner et al., 2014). Recently, governmental estimates indicated that in 2040, from 588 to 936 million tons of dry material will be available for harvest, of which 153 to 161 million tons will be from maize (U.S. Department of Energy, 2016).

Forest crop residues from wood, paper and cellulose industry are also reported as potential raw materials for bioenergy production (Koizumi, 2015), although the productive processes are incipient in comparison to agricultural residues. For arboreal species become economically feasible, it needs to produce wood with medium to high density and easily dryable, besides biochemical composition adequate for the production of bioenergy (Long et al., 2015), as well as be mechanically harvested throughout the year. A good example of a potential raw material is the eucalyptus (Eucalyptus spp.), which attends the largest part of these criteria and has high potential for productivity in short rotation periods (Seebaluck and Leal, 2015).

\section{Impacts of bioenergy crop residues on soil properties}

\section{i) Crop residues vs soil chemical properties}

The harvest of crop residues has changed the dynamics and availability of nutrients in the soil (e.g., Trivelin et al., 2013; Khanal et al., 2014; Karlen et al., 2014, 2015; Adler et al., 2015; Tan and Liu, 2015). Moreover, crop residues are an important source of nutrients for subsequent crops (Table 2). Accordingly, residue harvest for energy purposes might increase the demand for mineral fertilizers (Trivelin et al., 2013; Karlen et al., 2015). However, the impact of this practice on soil chemical properties are dependent on the harvest rates adopted (Franco et al., 2013; Khanal et al., 2014; Karlen et al., 2015).

In the short term, the harvest of residues could significantly alter the levels of $\mathrm{P}$ and $\mathrm{K}$, whilst, in the long term, the impacts are more relevant on the levels of $\mathrm{N}, \mathrm{Ca}$, $\mathrm{Mg}$, S and micronutrients (Sawyer and Mallarino, 2007; Jeschke and Heggenstaller, 2012). However, Karlen et al. (2015) showed that most research was carried out under temperate climates and did not evaluate the secondary

Table 2 - Nutrient content in dry mass of maize and sugarcane residues.

\begin{tabular}{|c|c|c|c|c|c|c|}
\hline Crop residue & $\mathrm{N}$ & $P$ & K & $\mathrm{Ca}$ & $\mathrm{Mg}$ & S \\
\hline & & & $-g$ & & & \\
\hline Maize & $5.9-6.5$ & $0.5-0.7$ & $7.9-12.8$ & $1.8-2.2$ & $1.4-1.8$ & $0.4-0.7$ \\
\hline Sugarcane' & $4.4-12.3$ & $0.8-1.3$ & $3.1-17.2$ & 3.3-13.1 & $1.1-6.0$ & $0.7-4.0$ \\
\hline
\end{tabular}


macronutrients and micronutrients, due to the increase in the cost of analyses and the crop removes only low quantities of these elements not changing the fertilization programs. In contrast, the evaluation of these nutrients might be important in tropical regions, which have highly weathered, nutrient poor and naturally acidic soils.

Crop residues with high C:N ratios may induce soil $\mathrm{N}$ immobilization by microorganisms and can even increase the short-term demand for $\mathrm{N}$ fertilizers (Trivelin et al., 2013; Karlen et al., 2014; Ferreira et al., 2016; Meier and Thorburn, 2016). Ferreira et al. (2016) verified an average $\mathrm{N}$ recovery from sugarcane straw after three crop cycles of $7.6 \mathrm{~kg} \mathrm{ha}^{-1}$ or $16 \%$ of the initial $\mathrm{N}$ content in straw, representing a limited contribution to crop nutrition (2\% of total $\mathrm{N}$ needs) in the short term. However, long-time maintenance of sugarcane straw promotes a gradual increase in the soil $\mathrm{N}$, reducing $\mathrm{N}$ fertilization rates in sugarcane crops (Robertson and Thorburn, 2007; Trivelin et al., 2013; Costa et al., 2014; Ferreira et al., 2016; Meier and Thorburn, 2016). On the other hand, Khanal et al. (2014) reported a reduction of $\mathrm{N}$ in the soil due to maize stover harvesting in Iowa, the United States. Therefore, from an environmental protection perspective, partial harvest of maize residues in regions with high $\mathrm{N}$ content in the soil could reduce the potentially leachable $\mathrm{N}$ and consequently the pollution of water bodies (Khanal et al., 2014).

Short-term reduction in soil $\mathrm{P}$ availability (Sawyer and Mallarino, 2007; Jeschke and Heggenstaller, 2012) after crop residue harvest is related to: (i) less $\mathrm{P}$ released during the mineralization process, and (ii) the lower adsorption of $\mathrm{P}$ to the soil minerals induced by increased soil organic matter (SOM) in systems with high $\mathrm{C}$ input via crop residues (Reddy et al., 2014). The quantity of $P$ removed in the maize grains is five-fold higher than the $\mathrm{P}$ content in the residue (Avila-Segura et al., 2011). However, the quantity of this element in the residue should not be neglected, since $0.76 \mathrm{~kg} \mathrm{ha}^{-1}$ of $\mathrm{P}$ is removed from the field per ton of maize stover (Karlen et al., 2014). Sugarcane straw contains about $0.41 \mathrm{~kg} \mathrm{ha}^{-1} \mathrm{P}$ per ton of straw (Trivelin et al., 2013), which represents $40 \%$ of the P up taken by the crop (Oliveira et al., 2010).

In plants, ionic $\mathrm{K}$ is not part of any organic structure and is released rapidly from the plant residue (Calonego et al., 2012). Crop residues present high concentrations of $\mathrm{K}$ (Table 1) thus the maintenance of this residue contributes to soil K accumulation (Sawyer and Mallarino, 2007; Calonego et al., 2012). Maize residues contain $73 \%$ of the total $\mathrm{K}$ extracted by the plant (Karlen et al., 2015) and the exportation of this nutrient could reach $62 \mathrm{~kg} \mathrm{ha}^{-1}$ (Karlen et al., 2014). In sugarcane, $42 \%$ of the total $\mathrm{K}$ extracted by the plant is in the straw (Oliveira et al., 2010) and the removal of $\mathrm{K}$ is approximately $80 \mathrm{~kg} \mathrm{ha}^{-1}$ (Franco et al., 2013).

Crop residue harvesting negatively affects the cycling, storage and availability of nutrients in the soil, whether in the short or the long-term (Tan and Liu, 2015). Thus, the correct replacement of the nutrient removed in crop residues should be perfomed in order to ensure sustainability to the system (Karlen et al., 2011a; Adler et al., 2015). Furthermore, some management strategies of residue harvesting could minimize nutrient removal. Several studies have shown that the concentration of nutrients vary depending on the part of the plant analyzed (e.g., Avila-Segura et al., 2011; Franco et al., 2013; Trivelin et al., 2013; Karlen et al., 2015). Therefore, whenever operationally possible, it should be collected only the parts of the plant where nutrient concentration is the lowest (e.g., dry lower leaves of sugarcane plants, dry cobs and/ or leaves from the lowest parts of the maize plants) could minimize nutrient removal due to crop residue harvesting for bioenergy production.

\section{ii) Crop residues vs soil physical properties}

The maintenance of crop residues in the field is a key factor for the proper functioning of many soil physical and hydraulic processes. Most studies have shown that crop residue harvest is associated with soil structural degradation (Wilhelm et al., 2004; Blanco-Canqui and Lal, 2009; Blanco-Canqui, 2013; Tormena et al., 2016), mainly because of lower $\mathrm{C}$ inputs into the soil (Karlen et al., 2011b; Tormena et al., 2016), the absence of mechanical protection that disperses the pressure caused by machine traffic (Braida et al., 2006) and additional wheel traffic over the field to collect and remove crop residue (Wilhelm et al., 2004). Structural degradation of soils induced by crop residue harvest is related to decreased macro-aggregation and aggregate stability (Wegner et al., 2015; Johnson et al., 2016), which consequently lead to soil compaction (Wilhelm et al., 2004; Blanco-Canqui and Lal, 2007; Roque et al., 2010). Soil compaction decreases macroporosity (Osborne et al., 2014) and increases mechanical resistance to root penetration (Rosim et al., 2012; Tormena et al., 2017), which decreases water availability to plants (Tormena et al., 2017).

Crop residues that cover the soil act as physical barriers, making it less susceptible to the erosive action of raindrops and wind (Hammerbeck et al., 2012; Franzluebbers, 2015; Johnson et al., 2016). Moreover, the maintenance of crop residues favors infiltration (Blanco-Canqui et al., 2007; Johnson et al., 2016; Valim et al., 2016) and storage of water in the soil (Peres et al., 2010; Xiukang et al., 2015; Tormena et al., 2017). Peres et al. (2010) observed that the presence of $15 \mathrm{Mg} \mathrm{ha}^{-1}$ of sugarcane straw covering the soil reduced water loss $(0-20 \mathrm{~cm}$ layer $)$ by approximately half when compared to uncovered soil. The higher infiltration rate and water storage reduce runoff speed, decreasing losses of soil (Blanco-Canqui and Lal, 2009) and nutrients (Martins Filho et al., 2009; Silva et al., 2012; Sousa et al., 2012). In a climate change scenario, the maintenance of crop residues on the soil might decrease the effects of droughts, as well as prevent soil losses by erosion due to the occurrence of more frequent heavy rains.

In addition, crop residues could act as a thermal isolator reducing the heat exchange between the soil and the atmosphere, consequently reducing the amplitude 
of diurnal soil temperurate. This impact is greater when the residue is fresh and decreases as the residue decays (Wilhelm et al., 2004). The temperature of soil-surface layer (seeding layer) might be reduced by 5 to $10^{\circ} \mathrm{C}$ when the soil is covered with maize stover (Lal, 2009) and $2{ }^{\circ} \mathrm{C}$ when covered with sugarcane straw (Moitinho et al., 2013). In addition, the effects of residues on soil temperature are a complex set of processes that result in less evaporation of water from the soil when it is covered with crop residues (Wilhelm et al., 2004).

\section{iii) Crop residues vs soil biological properties}

Biological attributes are more sensitive to soil management changes when compared to chemical and physical attributes (Kaschuk et al., 2011). Recently, there has been an increase in the number of studies to identify and quantify the effects of crop residue harvest on the soil biota. Under no-tillage, maize stover harvest has a significant influence on the ratio fungus: bacteria, especially in the topsoil, but the effects on the soil microbial community structure depend on the duration of this system, as well as the type of soil and climatic conditions (Lehman et al., 2014). The maintenance of maize stover contributes to stability of the microbial community through the seasons (Lou et al., 2011). Moreover, the retention of maize residues could significantly affect the structure of the bacterial and fungal communities, with an increase in the abundance of the genes responsible for $\mathrm{N}$ fixation (njfH) and denitrification (napA) (Wakelin et al., 2007).

Studies have shown the beneficial effects of crop residues maintenance on the control of some soil pests and diseases. Qi et al. (2015) reported that high concentrations (> $0.12 \mathrm{~g} \mathrm{~mL}^{-1}$ ) of compounds released during the decomposition of maize stover negatively affects germination, number and weight of the sclerotia of fungi Rhizoctonia and Bipolaris. Govaerts et al. (2007) observed that the increase in energy supply of microorganisms by keeping maize crop residues support the development of antagonists and predators in the soil, decreasing the population of phytoparasitic nematodes.

The harvest of residues from different bioenergy crops (Andropogon gerardii, Miscanthus $\times$ giganteus, Sorghum bicolor; Panicum virgatum; cv. Shawnee; and maize) showed no impact on total microbial biomass or on the microbial groups in annual or perennial systems. However, the restructuring of the soil microbial community is a gradual process, directly associated with changes in the quantity of organic material inputs, and therefore, should be considered a long-term effect (Orr et al., 2015).

Several studies conducted around the world have shown that the maintenance of sugarcane straw promotes increases in microbial biomass (Graham and Haynes, 2006; Souza et al., 2012; Paredes Jr. et al., 2015) and microbial community diversity (Rachid et al., 2013, 2016; Liao et al., 2014), especially in surface soil layers. In terms of soil macrofauna, despite the land-use change sequence, native vegetation-pasture-sugarcane induces a significant reduction in the diversity of macroinvertebrates (Franco et al., 2016), the remaining straw support the soil biota as a food source, improving microclimate conditions and as a shelter in sugarcane areas (Portilho et al., 2011; Benazzi et al., 2013). Portilho et al. (2011) verified a significant reduction in the richness and diversity of soil epigeic invertebrates in plots under total sugarcane straw removal when compared to those without straw removal. The presence of sugarcane straw supported the soil macrofauna, although increased quantities did not cause significant effects (Abreu et al., 2014). Moreover, the maintenance of sugarcane straw on the soil might promote the multiplication of natural enemies and inhibit proliferation of phytoparasitic nematodes that cause significant damage to sugarcane plantations (Dinardo-Miranda and Fracasso, 2013). On the other hand, the maintenance of sugarcane straw also supports the proliferation of important sugarcane pests such as the root spittlebug [Mahanarva fimbriolata (Hemiptera; Cercopidae)] and the sugarcane weevil (Sphenophorus levis Vaurie (Coleoptera: Curculionidae) (Dinardo-Miranda and Fracasso, 2013), and if these pests are not properly controlled, they may cause significant losses in sugarcane yields.

\section{iv) Crop residues vs soil C stocks}

Soil carbon stocks in agricultural areas depend predominantly on two factors: i) the dynamics of SOM decomposition and ii) $\mathrm{C}$ input into the soil. Therefore, crop residues are the principal $\mathrm{C}$ input in agricultural soils (Poeplau and Don, 2015). In Brazil, the higher biomass production of the main crops, associated with $\mathrm{C}$ depletion at a large rate of the soils, determine a positive soil $\mathrm{C}$ balance in most sites where crop residues are kept in the field (Figure 1).

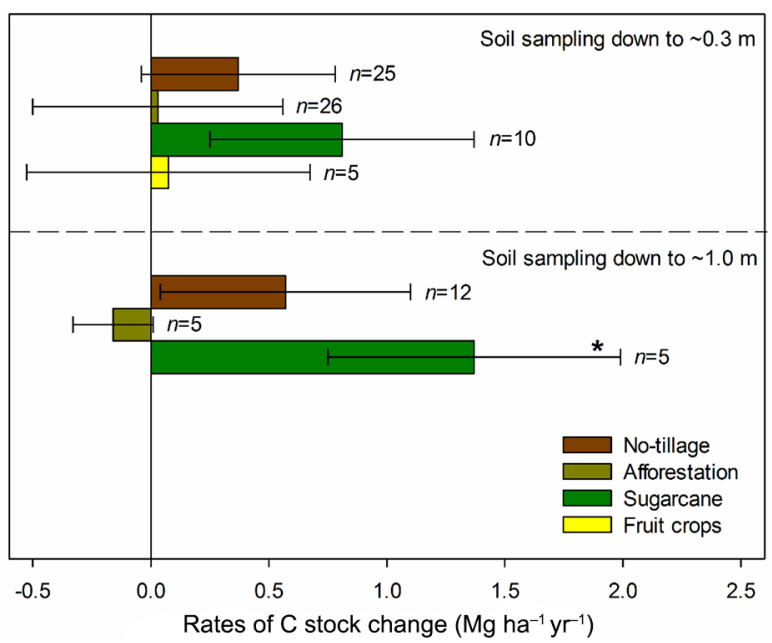

Figure 1 - Rates of $\mathrm{C}$ stock change ( $\left.\mathrm{Mg} \mathrm{ha}^{-1} \mathrm{yr}^{-1}\right)$ in the mainly Brazilian land uses related to high crop residues inputs. Estimates obtained from the studies in Appendix 1; Bars means standard deviation; * It includes two studies with soil sampling down to 0-0.6 m. 
Conservationist practices that prioritize the maintenance of crop residues, such as no-tillage, are considered one of the principal strategies for soil $\mathrm{C}$ accretion. Based on data obtained from studies published in the last 10 years, we calculated a rate of $C$ change of $0.37 \pm 0.41$ $\mathrm{Mg} \mathrm{ha} \mathrm{yr}^{-1} \mathrm{yr}^{-1}$ at the $0-0.3 \mathrm{~m}$ soil layer in no-tillage areas in Brazil (Figure 1). If the layer below one meter is considered, the rate increases to $0.57 \pm 0.53 \mathrm{Mg} \mathrm{ha}^{-1} \mathrm{yr}^{-1}$.

For a long time, $\mathrm{C}$ increases in no-tillage were attributed to absence of soil disturbance (e.g., Lal, 2004), because the natural aggregation of the soil is kept, protecting SOM against microbial respiration. However, this mechanism might not be the main reason for the increase in soil $\mathrm{C}$ in no-tillage areas, especially in highly weathered soils (Campos et al., 2011). In this context, the maintenance of crop residues emerges as the principal strategy to increase $C$ stocks in areas using no-tillage system. Through an extensive revision of 276 studies conductes worldwide, West and Post (2002) showed a direct relationship between the input of crop residues and the increase in soil $\mathrm{C}$ in no-tillage areas. In Brazil, soil C stocks showed a linear relationship with the annual input of crop residues, regardless of the soil preparation system (no-tillage or conventional tillage) (Campos et al., 2011). Recently, Carvalho et al. (2017) predicted soil C changes using the DayCent model in Nebraska (USA) induced by maize stover removal and tillage practices. The results showed that at $75 \%$ to $100 \%$ stover removal rates in areas under conventional tillage, reductions close to $1 \mathrm{Mg} \mathrm{ha}^{-1} \mathrm{yr}^{-1}$ of soil C stocks were observed; whereas under no-tillage, even at $100 \%$ maize stover removal, soil C stocks increased in relation to the baseline under conventional tillage.

In contrast to what occurs in areas with annual crops under no-tillage, the literature is unanimous in affirming that the principal factor associated with the increase in soil C stocks in sugarcane crops with the maintenance of the sugarcane straw (Cerri et al., 2011; Meir and Thorburn, 2016; Carvalho et al., 2017; Oliveira et al., 2017). Historically, the practice of burning before harvest was common in sugarcane crops in Brazil and is related to soil C stock depletion (Galdos et al., 2009; Cerri et al., 2011). With the gradual elimination of burning, a large quantity of sugarcane straw has been left on the soil. As these residues decay, part of the $\mathrm{C}$ is emitted as $\mathrm{CO}_{2}$ and part is incorporated into the soil, promoting increases in C stocks (Galdos et al., 2009; Cerri et al., 2011; Thorburn et al., 2012; Meir and Thorburn, 2016; Carvalho et al., 2017; Oliveira et al., 2017). In Brazil, field available data show an annual rate of $\mathrm{C}$ stock change in the soil in sugarcane crops without burning of $0.81 \pm 0.56$ and $1.37 \pm 0.62 \mathrm{Mg} \mathrm{ha}^{-1} \mathrm{yr}^{-1}$ for the $0-0.3$ $\mathrm{m}$ and 0-1.0 $\mathrm{m}$ layers, respectively (Appendix 1). In two recent estudies conducted by Carvalho et al. (2017) and Oliveira et al. (2017), 30-year soil C changes induced by sugarcane straw management were predicted using the DayCent model. Carvalho et al. (2017) verified that the maintenance of sugarcane straw in the field increased soil C by 0.19 and $0.09 \mathrm{Mg} \mathrm{ha}^{-1} \mathrm{yr}^{-1}$ at two study sites, whereas straw removal rates promoted slight decreases in soil C stocks comparated to areas without straw removal management. Oliveira et al. (2017) found a similar rate of soil C stocks accretion $\left(0.11 \mathrm{Mg} \mathrm{ha}^{-1} \mathrm{yr}^{-1}\right)$ when sugarcane straw is left on the field; however, they verified a significant decrease in soil C stocks /0.19 Mg ha ${ }^{-1} \mathrm{yr}^{-1}$ ) under $75 \%$ straw removal.

During the whole cycle, forest species deposit a large quantity of residues onto the soil due to the natural process of senescence. Furthermore, at harvesting, part of the biomass is left on the soil. The high $\mathrm{C}$ input in these areas is associated with increases in soil C stocks in afforestation areas worldwide (e.g., Paul et al., 2002; Shi et al., 2015). In Brazil, studies assessing soil $\mathrm{C}$ changes in areas under forests are divergent, while some report $\mathrm{C}$ accretion (Lima et al., 2006; Zinn et al., 2011), others point to equilibrium (Cook et al., 2014; Fialho and Zinn, 2014) and even reductions in $\mathrm{C}$ stocks in these areas (Soares et al., 2013). Based on these studies, changes in soil $\mathrm{C}$ stock averaged $0.03 \pm 0.53$ and $-0.16 \pm 0.17 \mathrm{Mg} \mathrm{ha}^{-1} \mathrm{yr}^{-1}$, in the 0-0.3 $\mathrm{m}$ and 0-1.0 $\mathrm{m}$ layers, respectively, in cultivated forests in Brazil (Figure 1). Although there are divergent results about the potential of forest plantations to increase soil C stocks (Appendix 1), the harvest of crop residue in these areas is clearly associated with a negative impact on SOM in different regions of the world (Kumaraswamy et al., 2014; Epron et al., 2015) and in Brazil (Versini et al., 2014). Furthermore, the maintenance of forest residues has a positive correlation with forest yield in Brazilian plantations (Gonçalves et al., 2013).

Few studies have assessed the impacts of fruit crops on soil $\mathrm{C}$ changes in Brazil (Appendix 1). Based on these studies, a rate of $\mathrm{C}$ accretion of $0.074 \pm 0.6 \mathrm{Mg}$ $\mathrm{ha}^{-1} \mathrm{yr}^{-1}$ for the 0-0.3 m layer was observed (Figure 1).

As discussed above, the maintenance of crop residues on the soil is one of the main factors associated with the positive soil $\mathrm{C}$ balance for some crops (Figure 1). Therefore, increasing crop residue harvest for bioenergy production can be associated with decreases in soil $\mathrm{C}$ stocks in areas with annual crops (e.g., Anderson-Teixeira et al., 2009; Blanco-Canqui, 2013; Liska et al., 2014; Wu et al., 2015; Carvalho et al., 2017), sugarcane (e.g., Carvalho et al., 2017; Oliveira et al., 2017) and afforestation (e.g., Hudiburg et al., 2011). Certainly, energy production from alternative biomass is essential for the transition to a low-C economy (Sanchez et al., 2015). However, since the use of bioenergy is supposed to mitigate GHG emissions, soil C losses and GHG emissions associated with crop residue harvest should be carefully evaluated.

In Brazil, the main scenario of crop residue harvest for bioenergy production occurs in sugarcane areas. However, only a few studies evaluate soil C stock responses to sugarcane straw harvest in these areas (Carvalho et al., 2017; Oliveira et al., 2017). Therefore, field research is essential to produce knowledge to support making decisions about investments and policies for the sugarcane industry. 


\section{Impact of crop residues on GHG emissions}

To date, there is no consensus on the real impact of crop residue harvest on GHG emissions of the soil. Some studies claim that the harvest of crop residues stimulate GHG emissions (Carmo et al., 2013; Liska et al., 2014). On the other hand, other studies indicate that residue harvest management does not alter GHG emissions (e.g., Baker et al., 2014; Guzman et al., 2015) or even reduce GHG emissions of the soil (Al-Kaisi and Guzman, 2012; Davis et al., 2012; Bentsen et al., 2014; Jin et al., 2014). Diverse factors affect directly or indirectly the production and emission of GHG, contributing to the variability of the results found in the literature. These factors could be environmental, edaphic and related to the quality and quantity of the material used to cover the soil (Pimentel et al., 2015).

In general, the largest GHG emissions are found when a large quantity of material is left on the soil surface (Carmo et al., 2013; Jin et al., 2014; Signor et al., 2014). Carmo et al. (2013) observed a decrease in emissions of 2.3 times under total straw harvest compared to $14 \mathrm{Mg} \mathrm{ha}^{-1}$ or $21 \mathrm{Mg} \mathrm{ha}^{-1}$ of sugarcane straw left on soil surface. A similar trend was observed under total maize stover harvest compared to no harvest (Jin et al., 2014).

Generally, an increase in soil $\mathrm{CO}_{2}$ emissions is observed with the maintenance of the crop residues in the field (Carmo et al., 2013; Baker et al., 2014; Jin et al., 2014; Signor et al., 2014). Jin et al. (2014) observed that maize stover harvest decreased soil total $\mathrm{CO}_{2}$ emissions by $4 \%$ compared to no stover harvest at nine sites across the US Corn Belt. However, $\mathrm{CO}_{2}$ from decomposition of residues is not counted in studies that produce inventories of GHG emission in agriculture, because this $\mathrm{CO}_{2}$ (biogenic) is cycled in the soil-plant-atmosphere continuum and it is distinguished from $\mathrm{CO}_{2}$ emitted from fossil fuels used for energy production, which accumulates in the atmosphere (Pourhashem et al., 2013). Nevertheless, crop residue harvest could favor $\mathrm{CO}_{2}$ emissions, due to the increase in temperature and reduction of moisture in the soil (Corradi et al., 2013; Guzman et al., 2015). The harvest of crop residues over the years should reduce organic $\mathrm{C}$ in the soil that could cause significant implications for $\mathrm{CO}_{2}$ emissions (Six et al., 2004).

The maintenance of crop residues on the soil could also promote the immediate increase in $\mathrm{N}_{2} \mathrm{O}$ emissions (Carmo et al., 2013; Jin et al., 2014). However, this scenario could be reversed in the long term, when mineralized $\mathrm{N}$ from straw becomes available to the plants (Meier and Thorburn, 2016). Thus, $\mathrm{N}$ inputs via crop residues can reduce the need for replacement via synthetic $\mathrm{N}$ fertilizers (Robertson and Thorburn, 2007; Davis et al., 2012; Trivelin et al., 2013; Costa et al., 2014; Ferreira et al., 2016; Meier and Thorburn, 2016), the main source of $\mathrm{N}_{2} \mathrm{O}$ emissions in agriculture (Smith et al., 2007; Guzman et al., 2015). In this sense, GHG emissions of $\mathrm{N}$ fertilizers in the agricultural phase have raised doubts about the environmental viability of replacing fossil fuels for maize ethanol (Crutzen et al.,
2008). Residue harvest can also cause an increase in soil temperature, stimulating microbial activity and $\mathrm{N}$ mineralization, resulting in higher $\mathrm{N}_{2} \mathrm{O}$ emissions from the soil (Mosier et al., 2002).

Signor et al. (2014) observed increases in $\mathrm{CH}_{4}$ emissions with the maintenance of sugarcane straw. On the other hand, various studies did not find a change in $\mathrm{CH}_{4}$ emissions from soils covered with straw (Carmo et al., 2013; Baker et al., 2014; Jin et al., 2014). Other studies did not consider $\mathrm{CH}_{4}$ emission in agricultural soils, due to its low emission in relation to $\mathrm{CO}_{2}$ and $\mathrm{N}_{2} \mathrm{O}$, lower than 1 and $10 \%$, respectively (Guzman et al., 2015). Lastly, it is possible that the crop residue harvest does not cause notable changes in factors that affect methanogenesis in the soil, such as redox potential (Agostinetto et al., 2002).

Field measurements of the effects of crop residue harvest on GHG emissions are still limited in Brazil and over the world (Carmo et al., 2013; Baker et al., 2014; Jin et al., 2014; Signor et al., 2014; Pitombo et al., 2015). Most studies on this issue have used model simulations (Searchinger et al., 2008; Davis et al., 2012; Campbell et al., 2014; Liska et al., 2014; Zhao et al., 2015; Cardozo et al., 2016), as well as life cycle analysis assessments (Macedo et al., 2008; Bordonal et al., 2012, 2015). For example, Liska et al. (2014) verified that the production of gasoline emits $7 \%$ less GHG when compared to the production of cellulosic ethanol from maize stover.

Besides the direct effects of using crop residues for bioenergy production, there are indirect effects, such as the decrease on land demand for feedstock production. Most uncertainties regarding biofuel sustainability are based on the GHG emissions associated with land-use change (Searchinger et al., 2008; Lapola et al., 2010). Therefore, cellulosic ethanol production might solve some of these issues, since there is no need to convert more land to increase production. According to Adler et al. (2007), the harvesting of $50 \%$ of the straw could increase ethanol production by $35 \%$ in maize areas, without the need to expand the area, reducing potential GHG emissions.

In general, crop residue harvest might reduce the direct and indirect GHG emissions in agricultural areas, increasing the sustainability of its industrial use. Moreover, the maintenance of a large quantity of straw in the field is improbable due to the economic perspective of cellulosic ethanol and bioelectricity. Therefore, future research should concentrate on responding questions regarding the ideal quantity of straw to be removed for the production of biofuels without increasing the GHG emissions.

\section{Impact of crop residues on growth and productivity of plants}

The management of crop residues can have direct and indirect effects on crop yield (Pittelkow et al., 2015). In tropical conditions, studies have shown different responses of plants to the maintenance of sug- 
arcane straw on the soil. Tavares et al. (2010) reported that straw maintenance on the soil surface improved tillering and final population of plants, which increased the stalk yield in relation to areas with straw burning. Conversely, Campos et al. (2010) found reduced tilling, growth and productivity of the plants at the end of the cycle when all straw was left on the soil surface.

In temperate zones, the full retention of the straw compromised sugarcane productivity, while the straw burning before harvest was associated with increased stalk yield (Wiedenfeld, 2009; Arceneaux and Selim, 2012). However, the beneficial effects of straw burning on productivity are generally restricted to the short term (Wiedenfeld, 2009; Viator and Wang, 2011).

In sub-tropical conditions, reduced sugarcane tillering (Olivier and Singels, 2006, 2012) and growth (Olivier and Singels, 2012) were observed with moderate amount of straw kept on the soil surface. Although there are possible negative effects of the straw in the crop establishment phase, no reduction in stalk yield was observed (Olivier and Singels, 2006, 2012). The negative effects of straw during the crop establishment phase might be associated to extracts released during the decomposition of sugarcane straw, which contain a large variety of functional groups such as phenols, alcohols, organic acids, ketones, ethers and aldehydes (Villegas et al., 2007). High concentrations of these biochemical substances could be toxic, affecting crop germination (Viator et al., 2006; Villegas et al., 2007).

Recent studies have shown that total harvest or maintenance of only $25 \%\left(5 \mathrm{Mg} \mathrm{ha}^{-1}\right)$ of the sugarcane straw reduces crop yield (Aquino and Medina, 2014; Aquino et al., 2015). In contrast, the maintenance of 50 $\%\left(10 \mathrm{Mg} \mathrm{ha}^{-1}\right)$ of the straw was sufficient to increase sugarcane root mass, which resulted in increased stalk yield (Aquino and Medina, 2014; Aquino et al., 2015).

In the United States, sustainability of the maize stover harvest depends on the management system. The maintenance of maize residues in no-tillage areas is associated with reduced seedling emergence (Dam et al., 2005) and the standing of plants in the establishment phase (Blanco-Canqui et al., 2006), plant growth (Sindelar et al., 2013), which can decrease grain productivity (Linden et al., 2000; Boomsma et al., 2010). Besides the effect of temperature regulation, the decay of maize stover also releases biochemical compounds that may affect plant growth (Qi et al., 2015). In contrast, stover harvest may also increase grain productivity (Karlen et al., 2014; Pantoja et al., 2015). However, the indiscriminate harvest of maize crop residues, even in areas under no tillage, might affect the system sustainability (BlancoCanqui and Lal, 2009), mainly in years with low rainfall (Linden et al., 2000).

Some studies indicate that the harvest of approximately $50 \%$ of maize residues had little effect on crop productivity (Kenney et al., 2015; Jin et al., 2015). On the other hand, the harvesting of values above $25 \%$ may reduce grain productivity in the subsequent har- vest (Blanco-Canqui and Lal, 2007, 2009). In some cases, whether the residues were kept or fully removed, little effect on maize productivity was observed (Dam et al., 2005). After evaluating different harvest strategies over a 4-year period, Birrell et al. (2014) concluded that maize stover harvest had little effect on the soil quality or crop yield. However, these authors suggested a continuous monitoring of soil fertility, soil $\mathrm{C}$ content and crop productivity to establish a sustainable long-term residue harvest management. The lack of a consensus about the quantity of maize crop residues that can be harvested without affecting crop productivity is justifiable, since the response of the crop to this practice depends on the location, soil type, topography and climate (Blanco-Canqui et al., 2006, 2007; Birrell et al., 2014).

Forestry residue harvest for bioenergy production has caused concern about the potential negative longterm effects on soil quality and wood productivity (Achat et al., 2015; Jang et al., 2015). Studies have shown that retention of forest residues increases the nutritional status and the productivity of eucalyptus trees (Mendham et al., 2003; Gonçalves et al., 2007; Rocha et al., 2016). Rocha et al. (2016) observed that the total removal of forest residues decreased wood production by $40 \%$ in the first and $6 \%$ in the second rotation of eucalyptus. On the other hand, in boreal forests, residue harvesting may not affect growth or productivity of the trees (Kaarakka et al., 2014). Global meta-analysis performed by Achat et al. (2015) showed that the harvesting of residues from forestry plantations reduced soil fertility, causing a reduction from 3 to $7 \%$ in the growth of the trees in subsequent cultivations.

\section{Incorporating best management practices for sustainable crop residue management}

Crop residues play essential roles to maintain or improve soil quality/health, plant growth and other ecosystem services, as discussed above. However, the benefits provided by crop residues left on field can be lost through indiscriminate harvest to produce bioenergy (e.g., biofuels and bioeletricity). Thus, crop residue management needs to be considered within a holistic view, integrating best management practices (BMPs) to attenuate adverse impacts caused by crop residue harvest. Best management practices that enhance the sustainability of residue harvest include replacement of soil nutrients removed with the residue, use of no-tillage and crop rotation, inclusion of annual or perennial cover crops, and the use of manure and other organic amendments (Blanco-Canqui and Lal, 2009; Karlen et al., 2011a; BlancoCanqui, 2013; Paustian et al., 2016).

The adoption of conservationist tillage could considerably increase the amount of collectable crop residues for industrial use without compromising soil $\mathrm{C}$ stocks (Carvalho et al., 2017). The absence of soil disturbance is one of the main drivers to prevent soil $\mathrm{C}$ losses in no-tillage systems (Segnini et al., 2013; Silva-Olaya et al., 2013; Oliveira et al., 2017). In sugarcane, soil till- 
age for unburned sugarcane renewal (every 5-6 years) could generate a loss equivalent to $80 \%$ of soil $\mathrm{C}$ that is potentially accumulated in this soil layer during one year of cultivation (Silva-Olaya et al., 2013). In annual crops, soil C losses are even higher, since soil tillage is performed every year.

Predictions using the DayCent model indicated that the effects of maize residue harvest on soil $\mathrm{C}$ stocks are much more severe under conventional tillage than in no-tillage in the US Corn Belt (Campbell et al., 2014; Carvalho et al., 2017), reaching a soil C loss rate of close to $1 \mathrm{Mg} \mathrm{ha}^{-1} \mathrm{yr}^{-1}$ (Carvalho et al., 2017). No-tillage rotations that include semi-perennial grasses or legumes also offer a promise to promote soil-profile $\mathrm{C}$ sequestration and improve soil resilience after residue removal (Blanco-Canqui, 2013). The sustainability of crop residue management under no-tillage can be enhanced by the introduction of cover crops into the agricultural system (Blanco-Canqui, 2013; Adner et al., 2015; Wegner et al., 2015). According to Blanco-Canqui (2013), no-tillage cover crops can sequester between 0.10 and $1 \mathrm{Mg}^{-1}$ $\mathrm{yr}^{-1}$ of $\mathrm{C}$ in relation to no-tillage without cover crops, depending on cover crop species, soil type, and precipitation input.

Considering the management of sugarcane straw for bioenergy production (cellulosic ethanol and bioelectricity), Oliveira et al. (2017) simulated some scenarios that well illustrated the potenciality of conservacionist management and other BMPs to mitigate the negative effects of straw removal on soil $\mathrm{C}$ accretion in Brazil (Figure 2). The authors reported that the rate of soil $\mathrm{C}$ loss due to sugarcane straw harvest decreases from 0.19 $\mathrm{Mg} \mathrm{ha}^{-1} \mathrm{yr}^{-1}$ (conventional cultivation) to $0.11 \mathrm{Mg} \mathrm{ha}^{-1}$ $\mathrm{yr}^{-1}$ when no-tillage is adopted. Although the adoption of no-tillage in sugarcane fields is not commom in Brazil, it is important to consider this practice during crop renovation, mainly in a scenario of straw removal with possible

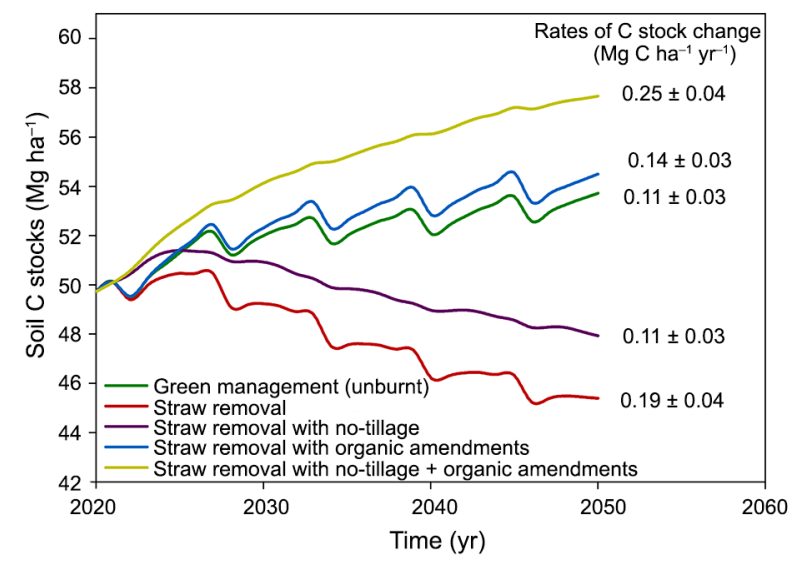

Figure 2 - Simulated soil $\mathrm{C}$ stocks at 0-0.3 m layer in sugarcane areas under green management, straw removal, and best management practices in Brazil; The reference for the rates of $\mathrm{C}$ stock change is the soil $\mathrm{C}$ stock in areas under green management by 2020; Source: Oliveira et al. (2017). soil C losses. Moreover, a positive soil $\mathrm{C}$ balance could be reached if an alternative $C$ source (e.g., vinasse, filtercake) were added (Figure 2), and an average increase in soil C stocks of $0.25 \mathrm{Mg} \mathrm{ha}^{-1} \mathrm{yr}^{-1}$ was observed when both practices (no-tillage and organic amendments) were adopted in sugarcane areas with straw removal (Oliveira et al., 2017).

To date, most research has focused on the effects of crop residue harvest on SOM, because of its multiple influences on soil properties and processes. Thus, conservacionist management practices can also increase nutrient cycling, water storage, biological activity as well as the soil resistance to structural degradation (Blanco-Canqui and Lal, 2009; Blanco-Canqui, 2013; Franzluebbers, 2015; Stavi et al., 2016). For instance, Tormena et al. (2016) observed through a visual evaluation method that deleterious impacts of high maize stover harvest on soil structural quality were magnified when a chisel plow was used as compared to no-tillage in Iowa (USA). The introduction of alfafa (cover crop) under no-tillage increased the available water and reduced the potential restriction of penetration resistance to crop growth (Tormena et al., 2017). In addition, no-tillage also can mitigate GHG emissions compared to conventional tillage, as reported by Silva-Olaya et al. (2013) and Jin et al. (2014).

Furthermore, integrated models and variable-removal technologies that allow the recognition of spatial heterogeneities in crop residue production and collection of a sustainable rate of crop residue harvest (i.e., based on soil characteristics, topography and management practices adopted) on the field or sub-field scale should be pursued (for instance, see Muth et al., 2012). It could prioritize a higher rate of residue harvest in areas with higher yields and lower potential for degradation, by erosion for example, minimizing the adverse environmental impacts caused by the spatially uniform management of crop residues.

\section{Final Remarks}

The use of crop residues for energy purposes is certainly one of the main alternatives to increase bioenergy production in the next few years. Without the need to expand the cultivated area, the threats against natural ecosystems and food production are greatly reduced. However, various trade-offs associated with crop residue harvest from the field were presented and discussed throughout this literature review and are summarized in Figure 3.

Consistently, literature reports that crop residue harvest has a negative impact on nutrient cycling and availability in the soil. Long-term nutrient removal by crop residues harvest impoverishes the soil, demanding their replacement using increasing quantities of mineral fertilizers. This produces an increase in production costs and greater impact on the environment. Furthermore, the reduction in the input of organic residues into the soil implies a direct reduction in $\mathrm{C}$ stocks, which nega- 

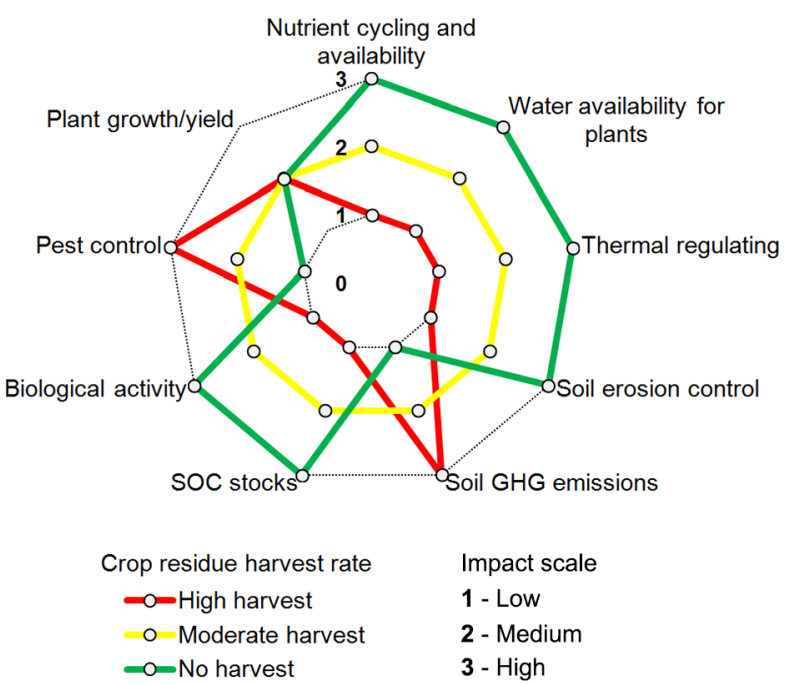

Figure 3 - Impacts of crop residue management on soil functions and plant growth. The soil functions and plant growth were graded for each crop residue harvest rate (high, moderate and low) according to the impact scale (i.e., 1 - low, 2 - medium and 3 high); Source: adapted from Stavi et al. (2016).

tively affects the soil biota. Deleterious effects from crop residue harvest extend from soil microbial to macrofauna communities. On the other hand, the increase in biological activity in the soil promoted by the maintenance of the residues has not only positive effects on the plants, but it also promotes the proliferation of pests, as it has been consistently reported in sugarcane fields. Crop residue harvest also makes the soil more susceptible to structural degradation, leading to compaction and consequently, resulting in lower infiltration and storage of water, and decreased plant root growth. Furthermore, crop residues act as physical/mechanical barriers that help to protect the soil against raindrop impact, which reduces the risk of erosion. In addition, crop residue mulch acts as a temperature isolator, reducing the amplitude of soil temperature and water evaporation.

The impacts of crop residue management on soil GHG emission are still not fully understood and demand more field studies. In general, the harvesting of residues reduce emissions of $\mathrm{CO}_{2}$ and $\mathrm{N}_{2} \mathrm{O}$ produced by decay and has no effects on $\mathrm{CH}_{4}$ emission. However, the gradual depletion of $\mathrm{C}$ and $\mathrm{N}$ stocks in the soil, associated with replacement of $\mathrm{N}$ via mineral fertilizers, could induce a negative $\mathrm{C}$ balance and higher $\mathrm{N}_{2} \mathrm{O}$ emissions in areas where the residues are harvested.

The plant response to crop residue management is site specific. Therefore, in addition to edaphoclimatic conditions that directly affect growth and crop productivity, factors intrinsic to the culture and management practices are determinants in the plant response to residue harvest. However, considering that residue management for bioenergy production is something recent, most experiments have been running for a few years, hindering assessment of the sustainability of this practice in the long term.

As crop residues have multiple funtions in the soil, affecting directly and indirectly diverse ecosystem services, investments in research to better understand the impact associated with residue management are essential to define strategies for the industrial use of this raw material. Additionally, the integrated planning of crop residue management, including best management practices (e.g. conservacionist tillage, crop rotation and cover crops, nutrient management and/or organic residues) can partially offset the adverse impacts caused by crop residue management, moving towards more sustainable bioenergy production.

Finally, collaboration networks between private and public institutions should be encouraged towards synchronizing the generation of knowledge and its application on a field scale, especially in Brazil, one of the world's major players in the bioenergy sector.

\section{Acknowledgments}

The authors wish to thank the Coordination for the Improvement of Higher Level Personnel (CAPES), the Brazilian National Council for Scientific and Technological Development (CNPq), São Paulo Research Foundation (FAPESP) (grants \# 2014/08632-9; 2015/14122-6; 2015/00308-0; 2016/08214-8) and the Luiz de Queiroz Agrarian Studies Foundation (FEALQ) (Project \# 67555) for providing scholarships. We would also like to thank the Brazilian Development Bank (BNDES) and the Raízen Energia S/A for funding our research (Project \#14.2.0773.1).

\section{References}

Abreu, R.R.L.; Lima, S.S.; Oliveira, N.C.R.; Leite, L.F.C. 2014. Edafic fauna under different straw levels in sugarcane crop. Pesquisa Agropecuária Tropical 44: 409-416 (in Portuguese, with abstract in English).

Achat, D.L.; Deleuze, C.; Landmann, G.; Pousse, N.; Ranger, J.; Augusto, L. 2015. Quantifying consequences of removing harvesting residues on forest soils and tree growth - A metaanalysis. Forest Ecology and Management 348: 124-141.

Adler, P.R.; Del-Grosso, S.J.; Parton, W.J. 2007. Life-cycle assessment of net greenhouse-gas flux for bioenergy cropping systems. Ecological Applications 17: 675-691.

Adler, P.R.; Rau, B.M.; Roth, G.W. 2015. Sustainability of corn stover harvest strategies in Pennsylvania. BioEnergy Research 8: 1310-1320.

Agostinetto, D.; Fleck, N.G.; Rizzardi, M.A.; Balbinot Jr, A.A. 2002. Methane emission potential in flooded rice fields. Ciência Rural 32: 1073-1081 (in Portuguese, with abstract in English).

Alburquerque, M.A.; Dieckow, J.; Sordi, A.; Piva, J.T.; Bayer, C.; Molin, R.; Pergher, M.; Ribeiro-Junior, P.J. 2015. Carbon and nitrogen in a Ferralsol under zero-tillage rotations based on cover, cash or hay crops. Soil Use and Management 31: 1-9. 
Al-Kaisi, M.; Guzman, J. 2012. Effects of maize residue removal on soil quality and greenhouse gas emissions in Iowa. Agrociencia Uruguay 16: 20-28.

Anderson-Teixeira, K.J.; Davis, S.C.; Masters, M.D.; Delucia, E.H. 2009. Changes in soil organic carbon under biofuel crops. Global Change Biology Bioenergy 1: 75-96.

Aquino, G.A.; Medina, C.C.; Porteira Jr., A.L.; Santos, L.O.; Cunha, A.C.B.; Kussaba, D.A.O.; Santos Jr., J.H.; Almeida, L.F.; Santiago, A.D. 2015. Root system and productivity of sugarcane ratoon associated to different quantities of straw. Pesquisa Agropecuária Brasileira 50: 1150-1159 (in Portuguese, with abstract in English).

Aquino, G.S.; Medina, C.C. 2014. Productivity and biometric and physiological indices of sugarcane grown under different amounts of straw. Pesquisa Agropecuária Brasileira 49: 173180 (in Portuguese, with abstract in English).

Arceneaux, A.E.; Selim, H.M. 2012. Mulch management strategies and sugarcane yield. Journal of the American Society of Sugar Cane Technologists 32: 28-37.

Assis, C.P.; Oliveira, T.S.; Dantas, J.D.A.N.; Mendonça, E.S. 2010. Organic matter and phosphorus fractions in irrigated agroecosystems in a semi-arid region of northeastern Brazil. Agriculture, Ecosystems \& Environment 138: 74-82.

Avila-Segura, M.; Barak, P.; Hedtcke, J.L.; Posner, J.L. 2011. Nutrient and alkalinitiy removal by corn grain, stover and cob harvest in Upper Midwest USA. Biomass and Bioenergy 35: 1190-1195.

Baker, J.M.; Fassbinder, J.; Lamb, J.A. 2014. The impact of corn stover removal on $\mathrm{N}_{2} \mathrm{O}$ emission and soil respiration: an investigation with automated chambers. Bioenergy Research 7: 503-508.

Bayer, C.; Martin-Neto, L.; Mielniczuk, J.; Pavinato, A.; Dieckow, J. 2006. Carbon sequestration in two Brazilian Cerrado soils under no-till. Soil and Tillage Research 86: 237-245.

Benazzi, E.D.; Bianchi, M.O.; Correia, M.E.F.; Lima, E.; Zonta, E. 2013. Impacts of harvesting methods of sugar cane on the soil macrofauna in production area in Espírito Santo - Brazil. Semina: Ciências Agrárias 34: 3425-3441 (in Portuguese, with abstract in English).

Bentsen, N.S.; Larsen, S.; Felby, C. 2014. $\mathrm{CO}_{2}$ emissions from crop residue-derived biofuels. Nature Climate Change 4: 932.

Birrell, S.J.; Karlen, D.L.; Wirt, A. 2014. Development of sustainable corn stover harvest strategies for cellulosic ethanol production. BioEnergy Research 7: 509-516.

Blanco-Canqui, H. 2013. Crop residue removal for bioenergy reduces soil carbon pools: how can we offset carbon losses? BioEnergy Research 6: 358-371.

Blanco-Canqui, H.; Lal, R. 2007. Soil and crop response to harvesting corn residues for biofuel production. Geoderma 141: 355-362.

Blanco-Canqui, H.; Lal, R. 2009. Crop residue removal impacts on soil productivity and environmental quality. Critical Reviews in Plant Sciences 28: 139-163.

Blanco-Canqui, H.; Lal, R.; Post, W.M.; Izaurralde, R.C.; Shipitalo, M.J. 2007. Soil hydraulic properties influenced by corn stover removal from no-till corn in Ohio. Soil and Tillage Research 92: 144-155.

Blanco-Canqui, H.; Lal, R.; Post, W.P.; Owens, L.B. 2006. Changes in long-term no-till corn growth and yield under different rates of stover mulch. Agronomy Journal 98: 1128-1136.
Boddey, R.M.; Jantalia, C.P.; Conceição, P.C.; Zanatta, J.A.; Bayer, C.; Mielniczuk, J.; Dieckow, J.; Santos, H.P.; Denardin, J.E.; Aita, C.; Giacomini, S.J.; Alves, B.J.R.; Urquiaga, S. 2010. Carbon accumulation at depth in Ferralsols under zero-till subtropical agriculture. Global Change Biology 16: 784-795.

Bonner, I.J.; Muth Jr., D.J.; Koch, J.B.; Karlen, D.L. 2014. Modeled impacts of cover crops and vegetative barriers on corn stover availability and soil quality. BioEnergy Research 7: 576-589.

Boomsma, C.R.; Santini, J.B.; West, T.D.; Brewer, J.C.; McIntyre, L.M.; Vyn, T.J. 2010. Maize grain yield responses to plant height variability resulting from crop rotation and tillage in a long term experiment. Soil and Tillage Research 106: 227-240.

Bordonal, R.D.; Figueiredo, E.B.; La Scala Jr, N. 2012. Greenhouse gas balance due to the conversion of sugarcane areas from burned to green harvest, considering other conservationist management practices. Global Change Biology Bioenergy 4: 846-858.

Bordonal, R.O.; Lal, R.; Aguiar, D.A.; Figueiredo, E.B.; Perillo, L.I.; Adami, M.; Rudorff, B.F.T.; La Scala, N. 2015. Greenhousegas balance from cultivation and direct land use change of recently established sugarcane (Saccharum officinarum) plantation in south-central Brazil. Renewable and Sustainable Energy Reviews 52: 547-556.

Braida, J.A.; Reichert, J.M.; Veiga, M.; Reinert, D.J. 2006. Mulch and soil organic carbon content and their relationship with the maximum soil density obtained in the proctor test. Revista Brasileira de Ciência do Solo 30: 605-614 (in Portuguese, with abstract in English).

Brandani, C.B.; Abbruzzini, T.F.; Williams, S.; Easter, M.; Cerri, C.E.P.; Paustian, K. 2015. Simulation of management and soil interactions impacting SOC dynamics in sugarcane using the CENTURY Model. Global Change Biology Bioenergy 7: 646-657.

Calonego, J.C.; Gil, F.C.; Rocco, V.F.; Santos, E.A. 2012. Persistence and nutrient release from maize, brachiaria and lablab straw. Bioscience Journal 28: 770-781 (in Portuguese, with abstract in English).

Campbell, E.E.; Johnson, J.M.F.; Jin, V.L.; Lehman, R.M.; Osborne, S.L.; Varvel, G.E.; Paustian, K. 2014. Assessing the soil carbon, biomass production, and nitrous oxide emission impact of corn stover management for bioenergy feedstock production using DAYCENT. BioEnergy Research 7: 491-502.

Campos, B.H.C.; Amado, T.J.C.; Bayer, C.; Nicoloso, R.S.; Fiorin, J.E. 2011. Carbon stock and its compartments in a subtropical oxisol under long-term tillage and crop rotation systems. Revista Brasileira de Ciência do Solo 35: 805-817.

Campos, L.H.F.; Carvalho, S.J.P.; Christoffoleti, P.J.; Fortes, C.F.; Silva, J.S. 2010. Straw management systems influence biomass accumulation and yield of sugarcane crop (var. RB855453). Acta Scientiarum. Agronomy 32: 345-350 (in Portuguese, with abstract in English).

Canellas, L.P.; Busato, J.G.; Dobbss, L.B.; Baldotto, M.A.; Rumjanek, V.M.; Olivares, F.L. 2010. Soil organic matter and nutrient pools under long-term non-burning management of sugar cane. European Journal of Soil Science 61: 375-383.

Cardozo, N.P.; Bordonal, R.O.; La Scala Jr., N. 2016. Greenhouse gas emission estimate in sugarcane irrigation in Brazil: is it possible to reduce it, and still increase crop yield? Journal of Cleaner Production 112: 3988-3997. 
Carmo, J.B.; Filoso, S.; Zotelli, L.C.; Sousa Neto, E.R.; Pitombo, L.M.; Duarte-Neto, P.J.; Vargas, V.P.; Andrade, C.A.; Gava, G.J.C.; Rossetto, R.; Cantarella, H.; Neto, A.E.; Martinelli, L.A. 2013. Infield greenhouse gas emissions from sugarcane soils in Brazil: effects from synthetic and organic fertilizer application and crop trash accumulation. Global Change Biology Bioenergy 5: 267-280.

Carvalho, J.L.N.; Cerri, C.E.P.; Feigl, B.J.; Piccolo, M.C.; Godinho, V.P.; Cerri, C.C. 2009. Carbon sequestration in agricultural soils in the Cerrado region of the Brazilian Amazon. Soil and Tillage Research 103: 342-349.

Carvalho, J.L.N.; Hudiburg, T.W.; Franco, H.C.J.; DeLucia, E.H. 2017. Contribution of above- and belowground bioenergy crop residues to soil carbon. Global Change Biology Bioenergy. DOI:10.1111/gcbb.12411

Carvalho, J.L.N.; Nogueirol, R.C.; Menandro, L.M.S.; Bordonal, R.O.; Borges, C.D.; Cantarella, H.; Franco, H.C.J. 2016. Agronomic and environmental implications of sugarcane straw removal: a major review. Global Change Biology Bioenergy. DOI:10.1111/gcbb.12410

Carvalho, J.L.N.; Otto, R.; Franco, H.C.J.; Trivelin, P.C.O. 2013. Input of sugarcane post-harvest residues into the soil. Scientia Agrícola 70: 336-344.

Cerri, C.C.; Galdos, M.V.; Maia, S.M.F.; Bernoux, M.; Feigl, B.J.; Powlson, D.; Cerri, C.E.P. 2011. Effect of sugarcane harvesting systems on soil carbon stocks in Brazil: an examination of existing data. European Journal of Soil Science 62: 23-28.

Conceição, P.C.; Dieckow, J.; Bayer, C. 2013. Combined role of no-tillage and cropping systems in soil carbon stocks and stabilization. Soil and Tillage Research 129: 40-47.

Cook, R.L.; Binkley, D.; Mendes, J.C.T.; Stape, J.L. 2014. Soil carbon stocks and forest biomass following conversion of pasture to broadleaf and conifer plantations in southeastern Brazil. Forest Ecology and Management 324: 37-45.

Corradi, M.M.; Panosso, A.R.; Martins Filho, M.V.; La Scala Junior, N. 2013. Crop residues on short-term $\mathrm{CO}_{2}$ emissions in sugarcane production areas. Engenharia Agrícola 33: 699708.

Costa, L.G.; Marin, F.R.; Nassif, D.S.; Pinto, H.M.; Lopes-Assad, M.L.R.C. 2014. Simulating trash and nitrogen management effects on sugar cane yield. Revista Brasileira de Engenharia Agrícola e Ambiental 18: 469-474 (in Portuguese, with abstract in English).

Crutzen, P.J.; Mosier, A.R.; Smith, K.A.; Winiwarter, W. 2008. $\mathrm{N}_{2} \mathrm{O}$ release from agro-biofuel production negates global warming reduction by replacing fossil fuels. Atmospheric Chemistry and Physics 8: 389-395.

Dam, R.F.; Mehdi, B.B.; Burgess, M.S.E.; Madramootoo, C.A.; Mehuys, G.R.; Callum, I.R. 2005. Soil bulk density and crop yield under eleven consecutive years of corn with different tillage and residue practices in a sandy loam soil in central Canada. Soil and Tillage Research 84: 41-53.

Davis, S.C.; Parton, W.J.; Del Grosso, S.J.; Keough, C.; Marx, E.; Adler, P.R.; DeLucia, E.H. 2012. Impact of second-generation biofuel agriculture on greenhouse-gas emissions in the corngrowing regions of the US. Frontiers in Ecology and the Environment 10: 69-74.
Diekow, J.; Mielniczuk, J.; Knicker, H.; Bayer, C.; Dick, D.P.; Kögel-Knabner, I. 2005. Soil C and N stocks as affected by cropping systems and nitrogen fertilisation in a southern Brazil Acrisol managed under no-tillage for 17 years. Soil and Tillage Research 81: 87-95.

Dinardo-Miranda, L.L.; Fracasso, J.V. 2013. Sugarcane straw and the populations of pests and nematodes. Scientia Agrícola 70: 369-374.

Economic Research Service [ERS]. 2015. U.S. Corn productivity and land use. Available at: http://www.afdc.energy.gov/ data/10337 [Accessed May 23, 2016]

Economic Research Service [ERS]. 2016. Global ethanol production. Available at: http://www.afdc.energy.gov/ data/10331 [Accessed May 23, 2016]

Empresa de Pesquisa Energética [EPE]. 2013. 10-year energy expansion plan = Plano decenal de expansão de energia 2021. Available at: http://www.epe.gov.br/PDEE/20130326_1.pdf [Accessed May 14, 2016] (in Portuguese).

Empresa de Pesquisa Energética [EPE]. 2015. Analysis of the biofuels scenario $=$ Análise de conjuntura dos biocombustíveis. Available at: http://www.epe.gov.br/Petroleo/ Documents/An\%C3\%A1lise\%20de\%20Conjuntura\%20 dos\%20Biocombust\%C3\%ADveis \% 20-\%20boletins \% 20 peri\%C3\%B3dicos/An\%C3\%A1lise\%20de\%20Conjuntura\%20 dos\%20Biocombust\%C3\%ADveis1\%20-\%20Ano\%202015.pdf [Accessed May 20, 2016] (in Portuguese).

Epron, D.; Mouanda, C.; Mareschal, L.; Koutika, L.S. 2015. Impacts of organic residue management on the soil $\mathrm{C}$ dynamics in a tropical eucalypt plantation on a nutrient-poor sandy soil after three rotations. Soil Biology and Biochemistry 85: 183-189.

Ferreira, D.A.; Franco, H.C.J.; Otto, R.; Vitti, A.C.; Fortes, C.; Faroni, C.E.; Garside, A.L.; Trivelin, P.C.O. 2016. Contribution of $\mathrm{N}$ from green harvest residues for sugarcane nutrition in Brazil. Global Change Biology Bioenergy 8: 859-866.

Fialho, R.C.; Zinn, Y.L. 2014. Changes in soil organic carbon under eucalyptus plantations in Brazil: a comparative analysis. Land Degradation \& Development 25: 428-437.

Figueiredo, E.B.; Panosso, A.R.; Reicosky, D.C.; La Scala, N. 2015. Short-term $\mathrm{CO}_{2}$-C emissions from soil prior to sugarcane (Saccharum spp.) replanting in southern Brazil. Global Change Biology Bioenergy 7: 316-327.

Fortes, C.; Trivelin, P.C.O.; Vitti, A.C. 2012. Long-term decomposition of sugarcane harvest residues in São Paulo state, Brazil. Biomass \& Bioenergy 42: 189-198.

Franco, A.L.C.; Bartz, M.L.C.; Cherubin, M.R.; Baretta, D.; Cerri, C.E.P.; Feigl., B.J.; Wall, D.H.; Davies, C.A.; Cerri, C.C. 2016. Loss of soil (macro) fauna due to the expansion of Brazilian sugarcane acreage. Science of the Total Environment 563-564: 160-168.

Franco, H.C.J.; Pimenta, M.T.B.; Carvalho, J.L.N.; Magalhães, P.S.G.; Rossell, C.E.V.; Braunbeck, O.A.; Vitti, A.C.; Kolln, O.T.; Neto, J.R. 2013. Assessment of sugarcane trash for agronomic and energy purposes in Brazil. Scientia Agrícola 70: 305-312.

Franzluebbers, A.J. 2015. Farming strategies to fuel bioenergy demands and facilitate essential soil services. Geoderma 259260: 251-258.

Galdos, M.V.; Cerri, C.C.; Cerri, C.E.P. 2009. Soil carbon stocks under burned and unburned sugarcane soil in Brazil. Geoderma 153: 347-352. 
Gomez, E.O.; Souza, R.T.G.; Rocha, G.J.M.; Almeida, E.; Cortez, L.A. 2010. Sugarcane straw as raw material for second generation processes $=$ Palha da cana-de-açúcar como matéria-prima para processos de segunda geração. p. 637660. In: Cortez, L.A.B., ed. Bioethanol from sugarcane: P\&D for productivity sustainability $=$ Bioetanol de cana-de-açúcar: P\&D para produtividade sustentabilidade. Edgard Blücher, São Paulo, SP, Brazil (in Portuguese).

Gonçalves, J.L.G.; Alvares, C.A.; Higa, A.R.; Silva, L.D.; Alfenas, A.C.; Stahl, J.; Ferraz, S.F.B.; Lima, W.P.; Brancalion, P.H.S.; Hubner, A.; Bouillet, J.D.; Laclau, J.; Nouvellon, Y.; Epron, D. 2013. Integrating genetic and silvicultural strategies to minimize abiotic and biotic constraints in Brazilian eucalypt plantations. Forest Ecology and Management 301: 6-27.

Gonçalves, J.L.M.; Wichert, M.C.P.; Gava, J.L.; Masetto, A.V.; Junior, A.J.; Serrano, M.I.P.; Mello, S.L.M. 2007. Soil fertility and growth of Eucalyptus grandis in Brazil under different residue management practices. Southern Hemisphere Forestry Journal 69: 95-102.

Govaerts, B.; Fuentes, M.; Mezzalama, M.; Nicol, J.M.; Deckers, J.; Etchevers, J.D.; Figueroa-Sandoval, B.; Sayre, K.D. 2007. Infiltration, soil moisture, root rot and nematode populations after 12 years of different tillage, residue and crop rotation managements. Soil and Tillage Research 94: 209-219.

Graham, M.H.; Haynes, R.J. 2006. Organic matter status and the size, activity and metabolic diversity of the soil microbial community in the row and inter-row of sugarcane under burning and trash retention. Soil Biology \& Biochemistry 38: 21-31.

Guimarães, D.V.; Gonzaga, M.I.; Melo Neto, J.D.O. 2014. Management of soil organic matter and carbon storage in tropical fruit crops. Revista Brasileira de Engenharia Agrícola e Ambiental 18: 301-306 (in Portuguese, with abstract in English).

Guzman, J.; Al-Kaisi, M.; Parkin, T. 2015. Greenhouse gas emissions dynamics as influenced by corn residue removal in continuous corn system. Soil Science Society of America Journal 13: 612-625.

Hammerbeck, A.L.; Stetson, S.J.; Osborne, S.L.; Schumacher, T.E.; Pikul, J.L. 2012. Corn residue removal impact on soil aggregates in a no-till corn/soybean rotation. Soil Science Society of America Journal 76: 1390-1398.

Hudiburg, T.W.; Law, B.E.; Wirth, C.; Luyssaert, S. 2011. Regional carbon dioxide implications of forest bioenergy production. Nature Climate Change 1: 419:423.

Intergovernmental Panel on Climate Change [IPCC]. 2007. Climate Change 2007: The Physical Science Basis; Summary for Policymakers. Intergovernmental Panel on Climate Change, Geneva, Switzerland.

International Renewable Energy Agency [IRENA]. 2016. Roadmap for a renewable energy future. Available at: http://www.irena. org/DocumentDownloads/Publications/IRENA_REmap_2016_ edition_report.pdf [Accessed Aug 18, 2016]

Jang, W.; Keyes, C.R.; Page-Dumroese, D.S. 2015. Impact of biomass harvesting on forest soil productivity in the northern Rocky Mountains. U.S. Department of Agriculture-Forest Service, Fort Collins, CO, USA. (RMRS-GTR-341).

Jeschke, M.; Heggenstaller, A. 2012. Sustainable corn stover harvest for biofuel production. Crop insights 22: 1-6.
Jin, V.L.; Baker, J.M.; Johnson, J.; Karlen, D.L.; Lehman, R.M.; Osborne, S.L.; Sauer,T.J.; Stott, D.E.; Varvel, G.E.; Venterea, R.T.; Schmer, M.R.; Wienhold, B.J. 2014. Soil greenhouse gas emissions in response to corn stover removal and tillage management across the US Corn Belt. BioEnergy Research 7: 517-527.

Jin, V.L.; Schmer, M.R.; Wienhold, B.J.; Stewart, C.E.; Varvel, G.E.; Sindelar, A.J.; Follett, R.F.; Mitchell, R.B.; Vogel, K.P. 2015. Twelve years of stover removal increases soil erosion potential without impacting yield. Soil Science Society of America Journal 79: 1169-1178.

Johnson, J.M.F.; Strock, J.S.; Tallaksen, J.E.; Reese, M. 2016. Corn stover harvest changes soil hydrology and soil aggregation. Soil and Tillage Research 161: 106-115.

Kaarakka, L.; Tamminen, P.; Saarsalmi, A.; Kukkola, M.; Helmisaari, H.S.; Burton, A.J. 2014. Effects of repeated wholetree harvesting on soil properties and tree growth in a Norway spruce (Picea abies (L.) Karst.) stand. Forest Ecology and Management 313: 180-187.

Karlen, D.L.; Birell, S.J.; Hess, J.R. 2011a. A five-year assessment of corn stover harvest in central Iowa, USA. Soil and Tillage Research 115-116: 47-55.

Karlen, D.L.; Birrell, S.J.; Johnson, J.M.F.; Osborne, S.L.; Schumacher, T.E.; Varvel, G.E.; Ferguson, R.B.; Novak, J.M.; Fredrick, J.R.; Baker, J.M.; Lamb, J.A.; Adler, P.R.; Roth, G.W.; Nafziger, E.D. 2014. Multilocation corn stover harvest effects on crop yields and nutrient removal. BioEnergy Research 7: 528-539.

Karlen, D.L.; Johnson, J.M.F. 2014. Crop residue considerations for sustainable bioenergy feedstock supplies. Bioenergy Research 7: 465-467.

Karlen, D.L.; Kovar, J.L.; Birrell, S.J. 2015. Corn stover nutrient removal estimates for central Iowa, USA. Sustainability 7 : 8621-8634.

Karlen, D.L.; Varvel, G.E.; Johnson, J.M.F.; Baker, J.M.; Osborne, S.L.; Novak, J.M.; Adler, P.R.; Roth, G.W.; Birrell, S.J. $2011 \mathrm{~b}$. Monitoring soil quality to assess the sustainability of harvesting corn stover. Agronomy Journal 103: 288-295.

Kaschuk, G.; Alberton, O.; Hungria, M. 2011. Quantifying effects of different agricultural land uses on soil microbial biomass and activity in Brazilian biomes: inferences to improve soil quality. Plant and Soil 338: 467-481.

Kenney, I.; Blanco-Canqui, H.; Presley, D.R.; Rice, C.W.; Janssen, K.; Olson, B. 2015. Soil and crop response to stover removal from rainfed and irrigated corn. Global Change Biology Bioenergy 7: 219-230.

Khanal, S.; Anex, R.P.; Gelder, B.K.; Wolter, C. 2014. Nitrogen balance in Iowa and the implications of corn-stover harvesting. Agriculture, Ecosystems \& Environment 183: 21-30.

Koizumi, T. 2015. Biofuels and food security. Renewable and Sustainable Energy Reviews 52: 829-841.

Kumaraswamy, S.; Mendham, D.S.; Grove, T.S.; O'Connell, A.M.; Sankaran, K.V.; Rance, S.J. 2014. Harvest residue effects on soil organic matter, nutrients and microbial biomass in eucalypt plantations in Kerala, India. Forest Ecology and Management 328: 140-149.

Lal, R. 2004. Soil carbon sequestration impacts on global climate change and food security. Science 304: 1623-1627. 
Lal, R. 2005. World crop residues production and implications of its use as a biofuel. Environment International 31: 575-584.

Lal, R. 2009. Soil quality impacts of residue removal for bioethanol production. Soil and Tillage Research 102: 233-241.

Landell, M.G.A.; Scarpari, M.S.; Xavier, M.A.; Anjos, I.A.; Baptista, A.S.; Aguiar, C.L.; Silva, D.N.; Bidóia, M.A.P.; Brancalião, S.R.; Bressiani, J.A.; Campos, M.F.; Miguel, P.E.M.; Silva, T.N.; Silva, V.H.P.; Anjos, L.O.S.; Ogata, B.H. 2013. Residual biomass potential of commercial and pre-commercial sugarcane cultivars. Scientia Agricola 70: 299-304.

Lapola, D.M.; Schaldach, R.; Alcamo, J.; Bondeau, A.; Koch, J.; Koelking, C.; Priess, J.A. 2010. Indirect land-use changes can overcome carbon savings from biofuels in Brazil. Proceedings of the National Academy of Sciences of the United States of America 107: 3388-3393.

Leal, M.R.L.V.; Galdos, M.V.; Scarpare, F.V.; Seabra, J.E.A.; Walter, A.; Oliveira, C.O.F. 2013. Sugarcane straw availability, quality, recovery and energy use: a literature review. Biomass and Bioenergy 53: 11-19.

Lehman, R.M.; Ducey, T.F.; Jin, V.L.; Acosta-Martinez, V.; Ahlschwede, C.M.; Jeske, E.S.; Drijber, R.A.; Cantrell, K.B.; Frederick, J.R.; Fink, D.M.; Osborne, S.L.; Novak, J.M.; Johnson, J.M.F.; Varvel, G.E. 2014. Soil microbial community response to corn stover harvesting under rain-fed, no-till conditions at multiple US locations. BioEnergy Research 7: 540-550.

Liao, Q.; Wei, G.; Chen, G.; Liu, B.; Huang, D.; Li, Y. 2014. Effect of trash addition to the soil on microbial communities and physico-chemical properties of soils and growth of sugarcane plants. Sugar Tech 16: 400-404.

Lima, A.M.; Silva, I.R.; Neves, J.C.; Novais, R.F.; Barros, N.F.; Mendonça, E.S.; Smyth, T.J.; Moreira, M.S.; Leite, F.P. 2006. Soil organic carbon dynamics following afforestation of degraded pastures with eucalyptus in southeastern Brazil. Forest Ecology and Management 235: 219-231.

Lima, A.M.; Silva, I.R.; Stape, J.L.; Mendonça, E.S.; Novais, R.F.; Barros, N.F.D.; Neves, J.C.L.; Paul, K.; Schulthais, F.; Polglase, P.; Raison, J. 2011. Modeling changes in organic carbon stocks for distinct soils in southeastern Brazil after four eucalyptus rotations using the century model. Revista Brasileira de Ciência do Solo 35: 833-847.

Linden, D.R.; Clapp, C.E.; Dowdy, R.H. 2000. Long-term corn grain and stover yields as a function of tillage and residue removal in east central Minnesota. Soil and Tillage Research 56: 167-74.

Liska, A.J.; Yang, H.; Milner, M.; Goddard, S.; Blanco-Canqui, H.; Pelton, M.P.; Fang, X.X.; Zhu, H.; Suyker, A.E. 2014. Biofuels from crop residue can reduce soil carbon and increase $\mathrm{CO}_{2}$ emissions. Nature Climate Change 4: 398-401.

Long, S.P.; Karp, A.; Buckeridge, M.S.; Davis, S.C.; Jaiswal, D.; Moore, P.H.; Moose, S.P.; Murphy, D.J.; Onwona-Agyeman, S.; Vonshakh, A. 2015. Feedstocks for biofuels and bioenergy. p. 302-346. In: Souza, G.M.; Victoria, R.; Joly, C.; Verdade, L.M., eds. Bioenergy \& sustainability: bridging the gaps. SCOPE, Paris, France.

Lou, Y.L.; Liang, W.; Xu, M.; He, X.; Wang, Y.; Zhao, K. 2011. Straw coverage alleviates seasonal variability of the topsoil microbial biomass and activity. Catena 86: 117-120.
Macedo, I.C.; Seabra, J.E.A.; Silva, J.E.A.R. 2008. Greenhouse gases emissions in the production and use of ethanol from sugarcane in Brazil: the 2005/2006 averages and a prediction for 2020. Biomass and Bioenergy 32: 582-595.

Manechini, C.; Ricci Júnior, A.; Donzelli, J.L. 2005. Benefits and problems of trash left in the field. p. 27-33. In: Hassuani, S.J.; Leal, M.R.L.V.; Macedo, I.C. Biomass power generation: sugar cane bagasse and trash. PNUD-CTC, Piracicaba, SP, Brazil.

Maquere, V.; Laclau, J.P.; Bernoux, M.; Saint-Andre, L.; Gonçalves, J.L.M.; Cerri, C.C.; Piccolo, M.C.; Ranger, J. 2008. Influence of land use (savanna, pasture, Eucalyptus plantations) on soil carbon and nitrogen stocks in Brazil. European Journal of Soil Science 59: 863-877.

Martins Filho, M.V.; Liccioti, T.T.; Pereira, G.T.; Marques Jr., J.; Sanchez, R.B. 2009. Soil and nutrients losses of an Alfisol with sugarcane crop residue. Engenharia Agrícola 29: 8-18 (in Portuguese, with abstract in English).

Meier, E.A.; Thorburn, P.J. 2016. Long term sugarcane crop residue retention offers limited potential to reduce nitrogen fertilizer rates in Australian wet tropical environments. Frontiers in Plant Science 7: 1017. DOI: 10.3389/fpls.2016.01017

Mendham, D.S.; O'Connell, A.M.; Grove, T.S.; Rance, S.J. 2003. Residue management effects on soil carbon and nutrient contents and growth of second rotation eucalypts. Forest Ecology and Management 181: 357-372.

Mitchell, R.B.; Schmer, M.R.; Anderson, W.F.; Jin, V.; Balkcom, K.S.; Kiniry, J.; Coffin, A.; White, P. 2016. Dedicated energy crops and crop residues for bioenergy feedstocks in the central and eastern USA. Bioenergy Research 9: 384-398.

Moitinho, M.R.; Padovan, M.P.; Panosso, A.R.; La Scala, N. 2013. Effect of soil tillage and sugarcane trash on $\mathrm{CO} 2$ emission. Revista Brasileira de Ciência do Solo 37: 1720-1728 (in Portuguese, with abstract in English).

Mosier, A.R.; Doran, J.W.; Freney, J.R. 2002. Managing soil denitrification. Journal of Soil Water Conservation 57: 505-512.

Mourtzinis, S.; Cantrell, K.B.; Arriaga, F.J.; Balkcom, K.S.; Frederick, J.R.; Karlen, D.L. 2016. Carbohydrate and nutrient composition of corn stover from three southeastern USA locations. Biomass and Bioenergy 85: 153-158.

Muth, D.J.; McCorkle, D.S.; Koch, J.B.; Bryden, K.M. 2012. Modeling sustainable agricultural residue removal at the subfield scale. Agronomy Journal 104: 970-981.

Oliveira, D.M.S.; Williams, S.; Cerri, C.E.P.; Paustian, K. 2017. Predicting soil $\mathrm{C}$ changes over sugarcane expansion in Brazil using the DayCent model. Global Change Biology Bioenergy. DOI: $10.1111 /$ gcbb. 12427

Oliveira, E.C.A.; Freire, F.J.F.; Oliveira, R.I.; Freire, M.B.G.S.; Simões Neto, D.E.; Silva, S.A.M. 2010. Nutrient extraction and export by fully irrigated sugarcane varieties. Revista Brasileira de Ciência do Solo 34: 1343-1342 (in Portuguese, with abstract in English).

Oliveira, S.P.; Lacerda, N.B.; Blum, S.C.; Escobar, M.E.O.; Oliveira, T.S. 2015. Organic carbon and nitrogen stocks in soils of northeastern Brazil converted to irrigated agriculture. Land Degradation \& Development 26: 9-21.

Olivier, F.C.; Singels, A. 2006. The effect of plant residue layers on water use and growth of irrigated sugarcane. Proceedings of the South African Sugar Technologists' Association 80: 178-81. 
Olivier, F.C.; Singels, A. 2012. The effect of crop residue layers on evapotranspiration, growth and yield of irrigated sugarcane. Water SA 38: 77-86.

Orr, M.; Gray, M.B.; Applegate, B.; Volenec, J.J.; Brouder, S.M.; Turco, R.F. 2015. Transition to second generation cellulosic biofuel production systems reveals limited negative impacts on the soil microbial community structure. Applied Soil Ecology 95: 62-72.

Osborne, S.L.; Johnson, J.M.F.; Jin, V.L.; Hammerbeck, A.L.; Varvel, G.E.; Schumacher, T.E. 2014. The impact of corn residue removal on soil aggregates and particulate organic matter. BioEnergy Research 7: 559-567.

Paes, L.A.D.; Oliveira, M.A. 2005. Potential trash biomass of the sugar cane plant. p. 19-23. In: Hassuani, S.J.; Leal, M.R.L.V.; Macedo, I.C. Biomass power generation: sugar cane bagasse and trash. PNUD-CTC, Piracicaba, SP, Brazil.

Pantoja, J.L.; Woli, K.P.; Sawyer, J.E.; Barker, D.W.; Al-Kaisi, M. 2015. Stover harvest and tillage system effects on corn response to fertilizer nitrogen. Soil Science Society of America Journal 79: 1249-1260.

Paredes Jr., F.P.; Portilho, I.I.R.; Mercante, F.M. 2015. Microbiological attributes of the soil under cultivation of sugar cane with and without burning straw. Semina: Ciências Agrárias 36: 151-163 (in Portuguese, with abstract in English).

Paul, K.I.; Polglase, P.J.; Nyakuengama, J.G.; Khanna, P.K. 2002. Change in soil carbon following afforestation. Forest Ecology and Management 168: 241-257.

Paustian, K.; Lehmann, J.; Ogle, S.; Reay, D.; Robertson, G.P.; Smith, P. 2016. Climate-smart soils. Nature 532: 49-57.

Pereira, S.C.; Maehara, L.; Machado, C.M.M.; Farinas, C.S. 2015. $2 \mathrm{G}$ ethanol from the whole sugarcane lignocellulosic biomass. Biotechnology for Biofuels 8: 1-16.

Peres, J.G.; Souza, C.F.; Lavorenti, N.A. 2010. Evaluation of the effects of sugarcane straw coverage in moisture and water loss of soil. Engenharia Agrícola 30: 875-886 (in Portuguese, with abstract in English).

Pimentel, L.G.; Weiler, D.A.; Pedroso, G.M.; Bayer, C. 2015. Soil $\mathrm{N}_{2} \mathrm{O}$ emissions following cover-crop residues application under two soil moisture conditions. Journal of Plant Nutrition and Soil Science 178: 631-640.

Pinheiro, É.F.M.; Lima, E.; Ceddia, M.B.; Urquiaga, S.; Alves, B.J.R.; Boddey, R.M. 2010. Impact of pre-harvest burning vs. trash conservation on soil carbon and nitrogen stocks on a sugarcane plantation in the Brazilian Atlantic forest region. Plant and Soil 333: 71-80.

Pitombo, L.M.; Carmos, J.B.; Hollander, M.; Rosseto, R.; López, M.V.; Cantarella, H.; Kuramae, E.E. 2015. Exploring soil microbial $16 \mathrm{~S}$ rRNA sequence data to increase carbon yield and nitrogen efficiency of a bioenergy crop. Global Change Biology and Bioenergy 8: 867-879.

Pittelkow, C.M.; Liang, X.; Linquist, B.A.; Groenigen, K.J.; Lee, J.; Lundy, M.E.; Gestel, N.; Six, J.; Venterea, R.T.; Kessel, C. 2015. Productivity limits and potentials of the principles of conservation agriculture. Nature 517: 365-368.

Poeplau, C.; Don, A. 2015. Carbon sequestration in agricultural soils via cultivation of cover crops: a meta-analysis. Agriculture, Ecosystems \& Environment 200: 33-41.
Portilho, I.I.R.; Borges, C.D.; Costa, A.R.; Salton, J.C.; Mercante, F.M. 2011. Residues of sugar cane crop and its effects on the epigeic invertebrate fauna. Semina: Ciências Agrárias 32: 959970 (in Portuguese, with abstract in English).

Pourhashem, G.; Adler, P.R.; McAloon, A.J.; Spatari, S. 2013. Cost and greenhouse gas emission tradeoffs of alternative uses of lignin for second generation ethanol. Environmental Research Letters 8: 1-13.

Qi, Y.Z.; Zhen, W.C.; Li, H.Y. 2015. Allelopathy of decomposed maize straw products on three soil-born diseases of wheat and the analysis by GC-MS. Journal of Integrative Agriculture 14: 88-97.

Rachid, C.T.C.C.; Pires, C.A.; Leite, D.C.A.; Coutinho, H.L.C.; Peixoto, R.S.; Rosado, A.S.; Salton, J.; Zanatta, J.A.; Mercante, F.M.; Angelini, G.A.R.; Balieiro, F.C. 2016. Sugarcane trash levels in soil affects the fungi but not bacteria in a short-term field experiment. Brazilian Journal of Microbiology 47: 322-326.

Rachid, C.T.C.C.; Santos, A.L.; Piccolo, M.C.; Balieiro, F.C.; Coutinho, H.L.C.; Peixoto, R.S.; Tiedje, J.M.; Rosado, A.S. 2013. Effect of sugarcane burning or green harvest methods on the Brazilian Cerrado soil bacterial community structure. Plos One 8: e59342.

Razafimbelo, T.; Barthes, B.; Larre-Larrouy, M.C.; De Luca, E.F.; Laurent, J.Y.; Cerri, C.C.; Feller, C. 2006. Effect of sugarcane residue management (mulching versus burning) on organic matter in a clayey Oxisol from southern Brazil. Agriculture, Ecosystems \& Environment 115: 285-289.

Reddy, D.D.; Kushwaha, S.; Srivastava, S.; Khamparia, R.S. 2014. Long-term wheat residue management and supplementary nutrient input effects on phosphorus fractions and adsorption behavior in a Vertisol. Communications in Soil Science and Plant Analysis 45: 541-554.

Robertson, F.A.; Thorburn, P.J. 2007. Management of sugarcane harvest residues: consequences for soil carbon and nitrogen. Australian Journal of Soil Research 45: 13-23.

Rocha, J.H.T.; Gonçalves, J.L.M.; Gava, J.L.; Godinho, T.O.; Melo, E.A.S.C.; Bazani, J.H.; Hubner, A.; Arthur, J.C.; Wichert, M.P. 2016. Forest residue maintenance increased the wood productivity of a Eucalyptus plantation over two short rotations. Forest Ecology and Management 379: 1-10.

Roque, A.A.O.; Souza, Z.M.; Barbosa, R.S.; Souza, G.S. 2010. Agricultural traffic control and soil physical attributes in sugarcane areas. Pesquisa Agropecuária Brasileira 45: 744-750 (in Portuguese, with abstract in English).

Rosim, D.C.; Maria, I.C.; Silva, R.L.; Silva, A.P. 2012. Soil compaction in a rhodic hapludox soil as influenced by straw management and quantity on surface. Bragantia 71: 502-508 (in Portuguese, with abstract in English).

Sanchez, D.L.; Nelson, J.H.; Johnston, J.; Mileva, A.; Kammen, D.M. 2015. Biomass enables the transition to a carbon-negative power system across western North America. Nature Climate Change 5: 230-234.

Santos, F.A.; Queiróz, J.H.; Colodette, J.L.; Fernandes, S.A.; Guimarães, V.M.; Rezende, S.T. 2012. Potential of sugarcane straw for ethanol production. Química Nova 35: 1004-1010 (in Portuguese, with abstract in English).

Sawyer, J.E.; Mallarino, A.P. 2007. Nutrient removal when harvesting corn stover. Available at: http://www.ipm.iastate. edu/ipm/icm/2007/8-6/nutrients.html [Accessed May 18, 2016] 
Searchinger, T.; Heimlich, R.; Houghton, R.A.; Dong, F.; Elobeid, A.; Fabiosa, J.; Tokgoz, S.; Hayes, D.; Yu, T. 2008. Use of U.S. croplands for biofuels increases greenhouse gases through emissions from land-use change. Science 319: 1238-1240.

Seebaluck, V.; Leal, M.R.L.V. 2015. Feedstock supply chains. p. 347-373. In: Souza, G.M.; Victoria, R.; Joly, C.; Verdade, L.M., eds. Bioenergy \& sustainability: bridging the gaps. SCOPE, Paris, France.

Segnini, A.; Carvalho, J.L.N.; Bolonhezi, D.; Milori, D.M.B.P.; Silva, W.T.L.; Simões, M.L.; Cantarella, H.; Maria, I.C.; MartinNeto, L. 2013. Carbon stock and humificationindex of organic matter affected by sugarcane straw and soil management. Scientia Agricola 70: 321-326.

Shi, S.W.; Zhang, P.; Ding, F. 2015. The impact of afforestation on soil organic carbon sequestration on the Qinghai plateau, China. Plos One 10: e0116591 DOI:10.1371/journal.pone.0116591

Signor, D.; Pissioni, L.L.M.; Cerri, C.E.P. 2014. Greenhouse gases emissions due to sugarcane trash on the soil. Bragantia 73: 113122 (in Portuguese, with abstract in English).

Silva, G.R.V.; Souza, Z.M.; Martins Filho, M.V.; Barbosa, R.S.; Souza, G.S. 2012. Soil, water and nutrient losses by interrill erosion from green cane cultivation. Revista Brasileira de Ciência do Solo 36: 963-970.

Silva-Olaya, A.M.; Cerri, C.E.P.; La Scala Jr., N.; Dias, C.T.S.; Cerri, C.C. 2013. Carbon dioxide emissions under different soil tillage systems in mechanically harvested sugarcane. Environmental Research Letters 8: 015014.

Sindelar, A.J.; Coulter, J.A.; Lamb, J.A.; Vetsch, J.A. 2013. Agronomic responses of continuous corn to stover, tillage, and nitrogen management. Agronomy Journal 105: 1498-1506.

Siqueira Neto, M.; Scopel, E.; Corbeels, M.; Cardoso, A.N.; Douzet, J.M.; Feller, C.; Piccolo, M.C.; Cerri, C.C.; Bernoux, M. 2010. Soil carbon stocks under no-tillage mulch-based cropping systems in the Brazilian Cerrado: an on-farm synchronic assessment. Soil and Tillage Research 110: 187-195.

Six, J.; Ogle, S.M.; Breidt, F.J.; Conant, R.T.; Mosier, A.R.; Paustian, K. 2004. The potential to mitigate global warming with no-tillage management is only realized when practiced in the long term. Global Change Biology 10: 155-160.

Smith, P.; Martino, D.; Cai, Z.C.; Gwary, D.; Janzen, H.; Kumar, P.; McCarl, B.; Ogle, S.; O'Mara, F.; Rice, C.; Scholes, B.; Sirotenko, O.; Howden, M.; McAllister, T.; Pan, G.; Romanenkov, V.; Schneider, U.; Towprayoon, S. 2007. Policy and technological constraints to implementation of greenhouse gas mitigation options in agriculture. Agriculture, Ecosystems \& Environment 118: 6-28.

Soares, E.M.B.; Silva, I.R.; Novais, R.F.; Hu, Y.Y.; Schmidt-Rohr, K. 2013. Alterations in molecular composition of humic substances from eucalypt plantation soils assessed by C-NMR spectroscopy. Soil Science Society of America Journal 77: 293-306.

Sousa, G.B.; Martins Filho, M.V.; Matias, S.S.R. 2012. Soil, organic matter and nutrients losses by water erosion in a slope with sugarcane straw, in Guariba, State of São Paulo. Engenharia Agrícola 32: 490-500 (in Portuguese, with abstract in English).

Souza, R.A.; Telles, T.S.; Machado, W.; Hungria, M.; Tavares Filho, J.; Guimarães, M.F. 2012. Effects of sugarcane harvesting with burning on the chemical and microbiological properties of the soil. Agriculture, Ecosystems \& Environment 155: 1-6.
Stape, J.L.; Binkley, D.; Ryan, M.G. 2008. Production and carbon allocation in a clonal Eucalyptus plantation with water and nutrient manipulations. Forest Ecology and Management 255: 920-930.

Stavi, I.; Bel, G.; Zaady, E. 2016. Soil functions and ecosystem services in conventional, conservation, and integrated agricultural systems: a review. Agronomy for Sustainable Development 36: 1-12.

Tan, Z.; Liu, S. 2015. Corn Belt soil carbon and macronutrient budgets with projected sustainable stover harvest. Agriculture, Ecosystems \& Environment 212: 119-126.

Tavares, O.C.H.; Lima, E.; Zonta, E. 2010. Sugarcane growth and productivity under different tillage and crop systems. Acta Scientiarum Agronomy 32: 61-68.

Thorburn, P.J.; Meier, E.A.; Collins, K.; Robertson, F.A. 2012. Changes in soil carbon sequestration, fractionation and soil fertility in response to sugarcane residue retention are sitespecific. Soil \& Tillage Research 120: 99-111.

Tormena, C.A.; Karlen, D.L.; Logsdon, S.; Cherubin, M.R. 2016. Visual soil structure effects of tillage and corn stover harvest in Iowa. Soil Science Society of America Journal 80: 720-726.

Tormena, C.A.; Karlen, D.L.; Logsdon, S.; Cherubin, M.R. 2017. Corn stover harvest and tillage impacts on near-surface soil physical quality. Soil and Tillage Research 166: 122-130.

Trivelin, P.C.O.; Franco, H.C.J.; Otto, R.; Ferreira, D.A.; Vitti, A.C.; Fortes, C.; Faroni, C.E.; Oliveira, E.C.A.; Cantarella, H. 2013. Impact of sugarcane trash on fertilizer requirements for São Paulo, Brazil. Scientia Agricola 70: 345-352.

U.S. Department of Energy. 2016. 2016 billion-ton report: advancing domestic resources for a thriving bioeconomy. Available at: https://energy.gov/sites/prod/files/2016/12/ f34/2016_billion_ton_report_12.2.16_0.pdf [Accessed May 27, 2016]

United Nations Conference on Trade and Development [UNCTAD]. 2016. Second-generation biofuel markets: state of play, trade and developing country perspectives. Available at: http://unctad.org/en/PublicationsLibrary/ditcted2015d8_ en.pdf [Accessed May 14, 2016]

Valim, W.C.; Panachuki, E.; Pavei, D.S.; Alves Sobrinho, T.; Almeida, W.S. 2016. Effect of sugarcane waste in the control of interrill erosion. Semina: Ciências Agrárias 37: 1155-1164.

Versini, A.; Mareschal, L.; Matsoumbou, T.; Zeller, B.; Ranger, J.; Laclau, J.P. 2014. Effects of litter manipulation in a tropical Eucalyptus plantation on leaching of mineral nutrients dissolved organic nitrogen and dissolved organic carbon. Geoderma 232: 426-436.

Viator, H.P.; Wang. J.J. 2011. Effects of residue management on yield after three production cycles of a long-term sugarcane field trial in Louisiana. American Society of Sugar Cane Technologists 31:15-25.

Viator, R.P.; Johnson, R.M.; Grimm, C.C.; Richard, E.P. 2006. Allelopathic, autotoxic, and hormetic effects of postharvest sugarcane residue. Agronomy Journal 98: 1526-1531.

Villegas, F.; Torres, J.F.; Larrahondo, J.E.; Restrepo, D.F. 2007. Allelopathic effects of sugarcane postharvest residue. Proceedings of the International Society of Sugar Cane Technologists 26: 374-378. 
Wakelin, S.A.; Colloff, M.J.; Harvey, P.R.; Marschner, P.; Gregg, A.L.; Rogers, S.L. 2007. The effects of stubble retention and nitrogen application on soil microbial community structure and functional gene abundance under irrigated maize. FEMS Microbiology Ecology 59: 661-670.

Wegner, B.R.; Kumar, S.; Osborne, S.L.; Schumacher, T.E.; Vahyala, I.E.; Eynard, A. 2015. Soil response to corn residue removal and cover crops in eastern south Dakota. Soil Science Society of America Journal 79: 1179-1187.

Wendling, B.; Jucksch, I.; Mendonca, E.S.; Alvarenga, R.C. 2010. Organic-matter pools of soil under pines and annual cultures. Communications in Soil Science and Plant Analysis 41: 17071722 .

West, T.O.; Post, W.M. 2002. Soil organic carbon sequestration rates by tillage and crop rotation: a global data analysis. Soil Science Society of America Journal 66: 1930-1946.

Wiedenfeld, B. 2009. Effects of green harvesting vs burning on soil properties, growth and yield of sugarcane in south Texas. Journal of the American Society of Sugar Cane Technologists 29: 102-109.

Wilhelm, W.W.; Johnson, J.M.F.; Hatfield, J.L.; Voorhees, W.B.; Linden, D.R. 2004. Crop and soil productivity response to corn residue removal: a literature review. Agronomy Journal 96: 1-17.
Wu, Y.; Liu, S.; Young, C.J.; Dahal, D.; Sohl, T.L.; Davis, B. 2015. Projection of corn production and stover-harvesting impacts on soil organic carbon dynamics in the U.S. temperate prairies. Scientific Reports 5: 10830. DOI: 10.1038/srep10830

Xiukang, W.; Zhanbina, L.; Yingying, X. 2015. Effects of mulching and nitrogen on soil temperature, water content, nitrate- $\mathrm{N}$ content and maize yield in the Loess Plateau of China. Agricultural Water Management 161: 53-64.

Zanatta, J.A.; Bayer, C.; Dieckow, J.; Vieira, F.C.B.; Mielniczuk, J. 2007. Soil organic carbon accumulation and carbon costs related to tillage, cropping systems and nitrogen fertilization in a subtropical Acrisol. Soil and Tillage Research 94: 510-519.

Zhao, G.; Bryan, B.A.; King, D.; Luo, Z.; Wang, E.; Yu, Q. 2015. Sustainable limits to crop residue harvest for bioenergy: maintaining soil carbon in Australia's agricultural lands. Global Change Biology Bioenergy 7: 479-487.

Zinn, Y.L.; Resck, D.V.S.; Lal, R. 2011. Eucalypt plantation effects on organic carbon and aggregation of three different-textured soils in Brazil. Soil Research 49: 614-624.

Appendix 1 - Rates of soil $\mathrm{C}$ stock change $\left(\mathrm{Mg} \mathrm{ha}^{-1} \mathrm{yr}^{-1}\right)$ in the mainly Brazilian land uses related to high crop residues inputs; Data obtained from studies published in the last 10 years (in English).

\begin{tabular}{|c|c|c|c|c|c|c|}
\hline Local (Lat) ${ }^{\mathrm{a}}$ & Soil Type & $\begin{array}{l}\text { Clay content } \\
\left(\mathrm{g} \mathrm{kg}^{-1 \mathrm{~b}}\right)\end{array}$ & Land Use ${ }^{c}$ & Sampling depth (m) & $\begin{array}{l}\text { C stock change } \\
\left(\mathrm{Mg} \mathrm{ha}^{-1} \mathrm{yr}^{-1 d}\right)\end{array}$ & Reference \\
\hline \multicolumn{7}{|c|}{ No-Tillage } \\
\hline $30^{\circ} 51^{\prime} \mathrm{S}$ & Acrisol & 220 & C-M & $0-0.175$ & 0.82 & Diekow et al., 2005 \\
\hline $30^{\circ} 51^{\prime} \mathrm{S}$ & Acrisol & 220 & C-M & $0-0.175$ & 0.86 & Diekow et al., 2005 \\
\hline $25^{\circ} 00^{\prime} \mathrm{S}$ & Ferralsol & 500 & C-M-W-S & $0-0.2$ & -0.01 & Alburquerque et al., 2015 \\
\hline $25^{\circ} 00^{\prime} \mathrm{S}$ & Ferralsol & 500 & C-M-W-S & $0-0.2$ & -0.05 & Alburquerque et al., 2015 \\
\hline $25^{\circ} 00^{\prime} \mathrm{S}$ & Ferralsol & 500 & C-M-W-S & $0-0.2$ & 0.02 & Alburquerque et al., 2015 \\
\hline $25^{\circ} 00^{\prime} \mathrm{S}$ & Ferralsol & 500 & A-M & $0-0.2$ & 0.23 & Alburquerque et al., 2015 \\
\hline $16^{\circ} 15^{\prime} \mathrm{S}$ & Typic Hapludox & 350 & M-S & $0-0.2$ & 0.30 & Bayer et al., 2006 \\
\hline $18^{\circ} 31^{\prime} S$ & Typic Hapludox & 650 & M-S-CO & $0-0.2$ & 0.60 & Bayer et al., 2006 \\
\hline $30^{\circ} 51^{\prime} \mathrm{S}$ & Acrisol & 220 & C-M-C & $0-0.2$ & 0.25 & Conceição et al., 2013 \\
\hline $30^{\circ} 51^{\prime} \mathrm{S}$ & Acrisol & 220 & C-M & $0-0.2$ & 0.18 & Conceição et al., 2013 \\
\hline $28^{\circ} 15^{\prime} S$ & Rhodic Ferralsol & 630 & C-S-C-S-C-M & $0-0.3$ & 0.25 & Boddey et al., 2010 \\
\hline $28^{\circ} 29^{\prime} \mathrm{S}$ & Rhodic Ferralsol & 640 & W-S & $0-0.3$ & -0.24 & Boddey et al., 2010 \\
\hline $28^{\circ} 30^{\prime} \mathrm{S}$ & Rhodic Ferralsol & 630 & W-S-W-M-C & $0-0.3$ & 0.35 & Boddey et al., 2010 \\
\hline $28^{\circ} 30^{\prime} \mathrm{S}$ & Rhodic Ferralsol & 630 & W-S-W-M-C & $0-0.3$ & 0.04 & Boddey et al., 2010 \\
\hline $28^{\circ} 36^{\prime} S$ & Oxisol & 520 & W-S-C & $0-0.3$ & 0.29 & Campos et al., 2011 \\
\hline $28^{\circ} 36^{\prime} S$ & Oxisol & 520 & C-S-C-M-C-W-S & $0-0.3$ & 0.51 & Campos et al., 2011 \\
\hline $12^{\circ} 29^{\prime} \mathrm{S}$ & Typic Hapludox & 730 & R-M-S & $0-0.3$ & 0.38 & Carvalho et al., 2009 \\
\hline SI & Latosols & 660 & $\mathrm{~S}-\mathrm{M} / \mathrm{SO} / \mathrm{Ml}$ & $0-0.3$ & 1.90 & Siqueira Neto et al., 2010 \\
\hline $30^{\circ} 51^{\prime} \mathrm{S}$ & Acrisol & 220 & C-M & $0-0.3$ & 0.32 & Zanatta et al., 2007 \\
\hline $30^{\circ} 51^{\prime} \mathrm{S}$ & Acrisol & 220 & C-M & $0-0.3$ & 0.40 & Zanatta et al., 2007 \\
\hline $30^{\circ} 51^{\prime} \mathrm{S}$ & Acrisol & 220 & C-M-C & $0-0.3$ & 0.65 & Zanatta et al., 2007 \\
\hline $28^{\circ} 15^{\prime} \mathrm{S}$ & Rhodic Ferralsol & 630 & C-S-C-S-C-M & $0-1$ & 1.11 & Boddey et al., 2010 \\
\hline $28^{\circ} 29^{\prime} \mathrm{S}$ & Rhodic Ferralsol & 640 & W-S & $0-1$ & -0.22 & Boddey et al., 2010 \\
\hline $28^{\circ} 29^{\prime} \mathrm{S}$ & Rhodic Ferralsol & 640 & C-M-W-S-C-S & $0-1$ & 0.52 & Boddey et al., 2010 \\
\hline $28^{\circ} 30^{\prime} \mathrm{S}$ & Rhodic Ferralsol & 630 & W-S-W-M-C-M & $0-1$ & 0.85 & Boddey et al., 2010 \\
\hline $28^{\circ} 30^{\prime} \mathrm{S}$ & Rhodic Ferralsol & 630 & W-S-W-M-C & $0-1$ & 0.48 & Boddey et al., 2010 \\
\hline $25^{\circ} 00^{\prime} \mathrm{S}$ & Ferralsol & 500 & C-M-W-S & $0-1.0$ & 0.06 & Alburquerque et al., 2015 \\
\hline
\end{tabular}

Continue... 
Appendix 1 - Continuation.

\begin{tabular}{|c|c|c|c|c|c|c|}
\hline $25^{\circ} 00^{\prime} \mathrm{S}$ & Ferralsol & 500 & C-M-W-S & $0-1.0$ & 0.14 & Alburquerque et al., 2015 \\
\hline $25^{\circ} 00^{\prime} \mathrm{S}$ & Ferralsol & 500 & C-M-S & $0-1.0$ & 0.28 & Alburquerque et al., 2015 \\
\hline $25^{\circ} 00^{\prime} \mathrm{S}$ & Ferralsol & 500 & A-M & $0-1.0$ & 0.50 & Alburquerque et al., 2015 \\
\hline $30^{\circ} 51^{\prime} \mathrm{S}$ & Acrisol & 220 & C-M & $0-1.075$ & 1.40 & Diekow et al., 2005 \\
\hline $30^{\circ} 51^{\prime} \mathrm{S}$ & Acrisol & 220 & C-M & $0-1.075$ & 1.48 & Diekow et al., 2005 \\
\hline \multicolumn{7}{|c|}{ Afforestation } \\
\hline $19^{\circ} 14^{\prime} \mathrm{S}$ & ud & 590 & Eucalyptus & $0-0.1$ & 0.35 & Lima et al., 2006 \\
\hline $18^{\circ} 42^{\prime} \mathrm{S}$ & ud & 700 & Eucalyptus & $0-0.1$ & 0.57 & Lima et al., 2006 \\
\hline $19^{\circ} 11^{\prime} \mathrm{S}$ & Ultisol & 120 & Eucalyptus & $0-0.1$ & -0.51 & Soares et al., 2013 \\
\hline $18^{\circ} 70^{\prime} \mathrm{S}$ & Ultisol & 100 & Eucalyptus & $0-0.1$ & 0.38 & Soares et al., 2013 \\
\hline $18^{\circ} 44^{\prime} \mathrm{S}$ & Oxisol & 740 & Eucalyptus & $0-0.1$ & 0.18 & Soares et al., 2013 \\
\hline $17^{\circ} 50^{\prime} \mathrm{S}$ & Oxisol & 770 & Eucalyptus & $0-0.1$ & -0.80 & Soares et al., 2013 \\
\hline $29^{\circ} 56^{\prime} S$ & Alfisol & 420 & Eucalyptus & $0-0.1$ & -0.33 & Soares et al., 2013 \\
\hline $\mathrm{Rw}$ & rw & rw & Eucalyptus & $0-0.2$ & -1.50 & Fialho and Zinn, 2014 \\
\hline $19^{\circ} 14^{\prime} \mathrm{S}$ & Oxisol/Inceptisol & 670 & Eucalyptus & $0-0.2$ & 0.07 & Lima et al., 2011 \\
\hline $19^{\circ} 45^{\prime} \mathrm{S}$ & Oxisol/Inceptisol & 490 & Eucalyptus & $0-0.2$ & 0.28 & Lima et al., 2011 \\
\hline $19^{\circ} 57^{\prime} \mathrm{S}$ & Oxisol/Inceptisol & 485 & Eucalyptus & $0-0.2$ & 0.15 & Lima et al., 2011 \\
\hline $18^{\circ} 42^{\prime} \mathrm{S}$ & Oxisol/Inceptisol & 605 & Eucalyptus & $0-0.2$ & 1.01 & Lima et al., 2011 \\
\hline $18^{\circ} 39^{\prime} \mathrm{S}$ & Oxisol/Inceptisol & 645 & Eucalyptus & $0-0.2$ & 0.43 & Lima et al., 2011 \\
\hline $18^{\circ} 46^{\prime} \mathrm{S}$ & Oxisol/Inceptisol & 760 & Eucalyptus & $0-0.2$ & 0.43 & Lima et al., 2011 \\
\hline $19^{\circ} 24^{\prime} \mathrm{S}$ & Oxisol/Inceptisol & 630 & Eucalyptus & $0-0.2$ & 0.02 & Lima et al., 2011 \\
\hline $19^{\circ} 56^{\prime} \mathrm{S}$ & Oxisol/Inceptisol & 530 & Eucalyptus & $0-0.2$ & 0.88 & Lima et al., 2011 \\
\hline $19^{\circ} 28^{\prime} \mathrm{S}$ & Red Latosol & 730 & Pinus & $0-0.2$ & -0.18 & Wendling et al., 2010 \\
\hline $17^{\circ} 25^{\prime} \mathrm{S}$ & Haplustoxes & 340 & Eucalyptus & $0-0.2$ & -0.03 & Zinn et al., 2011 \\
\hline $17^{\circ} 24^{\prime} \mathrm{S}$ & Haplustoxes & 623 & Eucalyptus & $0-0.2$ & -0.14 & Zinn et al., 2011 \\
\hline $17^{\circ} 00^{\prime} \mathrm{S}$ & Haplustoxes & 867 & Eucalyptus & $0-0.2$ & -0.09 & Zinn et al., 2011 \\
\hline $23^{\circ} 02^{\prime} \mathrm{S}$ & Ferralsols & 180 & Eucalyptus & $0-0.3$ & 0.07 & Maquere et al., 2008 \\
\hline $23^{\circ} 02^{\prime} \mathrm{S}$ & Ferralsols & 175 & Eucalyptus & $0-0.3$ & 0.04 & Maquere et al., 2008 \\
\hline $11^{\circ} 58^{\prime} \mathrm{S}$ & Typic Haplustox & 100 & Eucalyptus & $0-0.3$ & -0.90 & Stape et al., 2008 \\
\hline $\mathrm{Rw}$ & rw & rw & Eucalyptus & $0-0.4$ & 0.30 & Fialho and Zinn, 2014 \\
\hline $22^{\circ} 40^{\prime} \mathrm{S}$ & Typic Hapludox & 240 & Eucalyptus & $0-0.45$ & 0.03 & Cook et al., 2014 \\
\hline $22^{\circ} 40^{\prime} \mathrm{S}$ & Typic Hapludox & 210 & Pinus & $0-0.45$ & 0.00 & Cook et al., 2014 \\
\hline $23^{\circ} 02^{\prime} \mathrm{S}$ & Ferralsols & 180 & Eucalyptus & $0-1$ & -0.03 & Maquere et al., 2008 \\
\hline $23^{\circ} 02^{\prime} \mathrm{S}$ & Ferralsols & 175 & Eucalyptus & $0-1$ & -0.01 & Maquere et al., 2008 \\
\hline $17^{\circ} 25^{\prime} \mathrm{S}$ & Haplustoxes & 340 & Eucalyptus & $0-1.0$ & -0.21 & Zinn et al., 2011 \\
\hline $17^{\circ} 24^{\prime} \mathrm{S}$ & Haplustoxes & 623 & Eucalyptus & $0-1.0$ & -0.43 & Zinn et al., 2011 \\
\hline $17^{\circ} 00^{\prime} \mathrm{S}$ & Haplustoxes & 867 & Eucalyptus & $0-1.0$ & -0.14 & Zinn et al., 2011 \\
\hline \multicolumn{7}{|c|}{ Sugarcane } \\
\hline $21^{\circ} 22^{\prime} \mathrm{S}$ & Hapludox & Clayey & SG GM & $0-0.1$ & 0.65 & Razafimbelo et al., 2006 \\
\hline $21^{\circ} 30^{\prime} \mathrm{S}$ & Entisol & 370 & SG GM & $0-0.2$ & 0.4 & Canellas et al., 2010 \\
\hline $21^{\circ} 25^{\prime} \mathrm{S}$ & Haplustult & 150 & SG GM CT & $0-0.2$ & 1.16 & Figueiredo et al., 2015 \\
\hline $21^{\circ} 25^{\prime} \mathrm{S}$ & Haplustult & 150 & SG GM NT & $0-0.2$ & 0.39 & Figueiredo et al., 2015 \\
\hline $21^{\circ} 22^{\prime} \mathrm{S}$ & Typic Hapludox & 760 & SG GM & $0-0.2$ & 1.2 & Galdos et al., 2009 \\
\hline Es & es & es & SG GM CT & $0-0.3$ & 0.24 & Bordonal et al., 2012 \\
\hline Es & es & es & SG GM NT & $0-0.3$ & 0.3 & Bordonal et al., 2012 \\
\hline $15^{\circ} 19^{\prime} \mathrm{S}$ & Typic Hapludox & 621 & SG & $0-0.3$ & 1.05 & Brandani et al., 2015 \\
\hline $\mathrm{Rw}$ & rw & Clay & SG GM & $0-0.3$ & 2.04 & Cerri et al., 2011 \\
\hline $\mathrm{Rw}$ & rw & Sand & SG GM & $0-0.3$ & 0.73 & Cerri et al., 2011 \\
\hline $\mathrm{SI}$ & sl & sl & SG GM & $0-0.6$ & 1.1 & Carvalho et al., 2013 \\
\hline $21^{\circ} 12^{\prime} \mathrm{S}$ & Oxisol & 570 & SG GM CT & $0-0.6$ & 0.67 & Segnini et al., 2013 \\
\hline $21^{\circ} 12^{\prime} \mathrm{S}$ & Oxisol & 570 & SG GM NT & $0-0.6$ & 1.63 & Segnini et al., 2013 \\
\hline $21^{\circ} 22^{\prime} \mathrm{S}$ & Typic Hapludox & 760 & SG GM & $0-1.0$ & 2.5 & Galdos et al., 2009 \\
\hline $19^{\circ} 18^{\prime} \mathrm{S}$ & Haplic Acrisol & 250 & SG GM & $0-1.0$ & 0.93 & Pinheiro et al., 2010 \\
\hline \multicolumn{7}{|c|}{ Fruit crops } \\
\hline $10^{\circ} 19^{\prime} \mathrm{S}$ & Ultisols & ud & Banana & $0-0.3$ & 0.8 & Guimarães et al., 2014 \\
\hline $10^{\circ} 19^{\prime} \mathrm{S}$ & Ultisols & ud & Citrus & $0-0.3$ & -1.69 & Guimarães et al., 2014 \\
\hline $5^{\circ} 09^{\prime} \mathrm{S}$ & Eutric Cambisol & 261 & Banana & $0-0.4$ & 0.09 & Assis et al., 2010 \\
\hline $5^{\circ} 08^{\prime} \mathrm{S}$ & Haplocambid & 261 & Banana & $0-0.5$ & 1.48 & Oliveira et al., 2015 \\
\hline $5^{\circ} 08^{\prime} \mathrm{S}$ & Haplocambid & 400 & Guava & $0-0.5$ & -0.31 & Oliveira et al., 2015 \\
\hline
\end{tabular}

